\title{
Glacial areas, lake areas, and snow lines from 1975 to 2012: status of the Cordillera Vilcanota, including the Quelccaya Ice Cap, northern central Andes, Peru
}

\author{
M. N. Hanshaw and B. Bookhagen \\ Department of Geography, University of California, Santa Barbara, CA, USA \\ Correspondence to: M. N. Hanshaw (mnhanshaw@gmail.com)
}

Received: 14 December 2012 - Published in The Cryosphere Discuss.: 25 February 2013

Revised: 19 December 2013 - Accepted: 10 January 2014 - Published: 3 March 2014

\begin{abstract}
Glaciers in the tropical Andes of southern Peru have received limited attention compared to glaciers in other regions (both near and far), yet remain of vital importance to agriculture, fresh water, and hydropower supplies of downstream communities. Little is known about recent glacial-area changes and how the glaciers in this region respond to climate changes, and, ultimately, how these changes will affect lake and water supplies. To remedy this, we have used 158 multi-spectral satellite images spanning almost 4 decades, from 1975 to 2012, to obtain glacial- and lake-area outlines for the understudied Cordillera Vilcanota region, including the Quelccaya Ice Cap. Additionally, we have estimated the snow-line altitude of the Quelccaya Ice Cap using spectral unmixing methods. We have made the following four key observations: first, since 1988 glacial areas throughout the Cordillera Vilcanota (1988 glacial area: $361 \mathrm{~km}^{2}$ ) have been declining at a rate of $3.99 \pm 1.15 \mathrm{~km}^{2} \mathrm{yr}^{-1}$ (22 year average, 1988-2010, with $95 \%$ confidence interval (CI), $n=8$ images). Since 1980, the Quelccaya Ice Cap (1980 glacial area: $\left.63.1 \mathrm{~km}^{2}\right)$ has been declining at a rate of $0.57 \pm 0.10 \mathrm{~km}^{2} \mathrm{yr}^{-1}$ (30 year average, 1980-2010, with $95 \%$ CI, $n=14$ ). Second, decline rates for individual glacierized regions have been accelerating during the past decade (2000-2010) as compared to the preceding decade (1988-1999) with an average increase from 37.5 to $42.3 \times 10^{-3} \mathrm{~km}^{2} \mathrm{yr}^{-1} \mathrm{~km}^{-2}$ (13\%). Third, glaciers with lower median elevations are declining at higher rates than those with higher median elevations. Specifically, glaciers with median elevations around $5200 \mathrm{~m}$ a.s.l. are retreating to higher elevations at a rate of $\sim 1 \mathrm{~m} \mathrm{yr}^{-1}$ faster than glaciers with median elevations around $5400 \mathrm{~m}$ a.s.l. Fourth,
\end{abstract}

as glacial regions have decreased, $77 \%$ of lakes connected to glacial watersheds have either remained stable or shown a roughly synchronous increase in lake area, while $42 \%$ of lakes not connected to glacial watersheds have declined in area (58\% have remained stable). Our new and detailed data on glacial and lake areas over 37 years provide an important spatiotemporal assessment of climate variability in this area. These data can be integrated into further studies to analyze inter-annual glacial and lake-area changes and assess hydrologic dependence and consequences for downstream populations.

\section{Introduction}

Glaciers are thought of as excellent indicators of climate change, as small climate variations can produce rapid glacial changes (e.g., Soruco et al., 2009; IPCC, 2007; Vuille et al., 2008a; Rabatel et al., 2013). Changes to small tropical glaciers, such as those found in the central Andes of South America, are difficult to predict as the coarse resolution of global climate models makes resolving the steep topography of mountain areas difficult (Vuille et al., 2008a). Yet glacial retreat and mass-balance loss as a result of warming trends may have significant consequences in this region: the current state and future fate of Andean glaciers and seasonal snow cover are of central importance for the water, food, and power supplies of densely populated regions in countries including Peru and Bolivia (Kaser et al., 2010; Barnett et al., 2005; Bradley et al., 2006). Despite heavy dependence on the seasonal buffering provided by Andean glacial meltwater 
(e.g., $\sim 80 \%$ of Peru's energy is hydropower) (Vergara et al., 2007), observation and understanding of these terrestrial water stores and fluxes remains poor. Additionally, glacial retreat not only has consequences for water supplies, but also for related natural hazards, including avalanches and glacial lake outburst floods (GLOFs), which are likely to become more common (Huggel et al., 2002, 2010; Carey, 2005).

Glaciers in many parts of the tropical Andes are retreating and losing mass (IPCC, 2007; Vuille et al., 2008a; Bradley et al., 2006; Rabatel et al., 2013). Mass-balance studies exist throughout the central Andes (Vuille et al., 2008b; Kaser and Georges, 1999; Thompson et al., 2006; Soruco et al., 2009; Rabatel et al., 2013), but are both spatially and temporally limited. Consequently, little is known about the timescales and equilibrium conditions of the vast majority of tropical Andean glaciers, and how climate variability affects their mass balances. In Peru, most studies have focused on glaciers in the Cordillera Blanca, which represents the largest glacierized mountain range in the tropics (Georges, 2004; Silverio and Jaquet, 2005; Racoviteanu et al., 2008a). However, the second largest mountain range in Peru, the Cordillera Vilcanota (CV), south-east of the Cordillera Blanca (Fig. 1), has received much less attention to date. The $\mathrm{CV}$ is home to the Quelccaya Ice Cap (QIC), the earth's largest tropical ice cap, one of the few sites of long-term glacier research in this region; Dr. Lonnie Thompson and his Ohio State University research group have been visiting and monitoring the ice cap since 1974. While Thompson and others (Thompson, 1980; Thompson et al., 1979, 1985, 2006; Brecher and Thompson, 1993; Hastenrath, 1978, 1998) have a long research history in the Quelccaya region, others are continuing research in this region also (e.g., Salzmann et al., 2013; Mark et al., 2002; Albert, 2002, 2007; Klein and Isacks, 1999).

As an icon of Andean glaciology and a region where glacial outlines are still minimal or lacking, for this study we have focused on the CV region and the QIC, where, according to Salzmann et al. (2013), "a comprehensive study on recent glacier changes ... is still lacking". While their study begins to address this, our study goes further to fill the data paucity in this region by using a total of 158 multispectral satellite images to obtain glacier and lake area outlines in the $\mathrm{CV}$ region, for a time series that spans almost 4 decades (1975-2012). Additionally, we approximate the snow-line altitude of the QIC using three images, spanning 21 years (1988-2009). We detail the methods used to outline the glacierized areas in this region, in addition to many of the lakes, specifically proglacial, not subglacial or supraglacial lakes. In some previous lake classification studies, Huggel et al. (2002) investigated a method to delineate lakes for assessing the hazards of GLOFs in the Swiss Alps, while Wessels et al. (2002) focused on supraglacial lakes and the methods used to delineate those in the Himalayas. Gardelle et al. (2011) used a combination of the two methods to investigate proglacial and supraglacial lakes in the Himalayas, but as of yet no studies have focused on lakes in the CV of Peru.

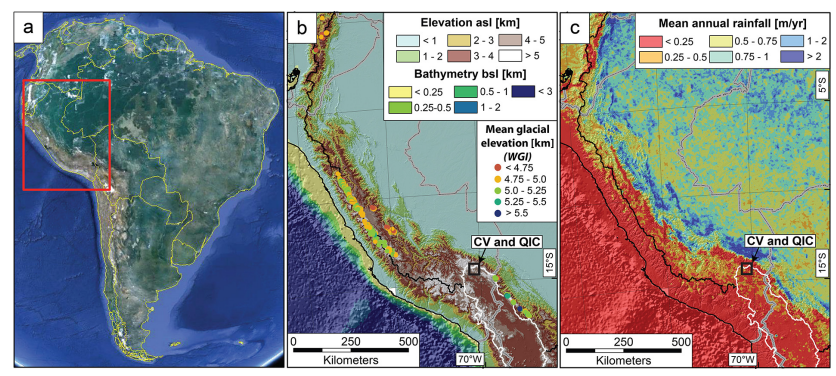

Fig. 1. Location of the study area - (a) South American continent, (b) topography and (c) rainfall for the northern and central Andes. Red rectangle in (a) indicates the area covered in panels (b) and (c). Included in (b) are some tropical glaciers (colored according to mean glacial elevation) from the World Glacier Inventory (WGMS and NSIDC, 1989), and in (b) and (c) the Amazon drainage basin is denoted by the thin black line, and the northern part of the internally drained Altiplano-Puna Plateau is displayed by a white line. Topography (b) is derived from the Shuttle Radar Topography Mission (SRTM) DEM, and mean annual rainfall (c) is based on satellite-derived estimates using Tropical Rainfall Measurement Mission (TRMM) product 2B31 averaged from 1998 to 2010 (Bookhagen and Strecker, 2008, 2012; Bookhagen and Burbank, 2010). The small black rectangle in panels (b) and (c) indicates the more specific study area of the Cordillera Vilcanota (CV) and the Quelccaya Ice Cap (QIC). Image in (a) is courtesy of Google Earth.

With populations highly dependent on the glaciers and their meltwaters (in this case, specifically, the moderately densely populated region of Cusco; Salzmann et al., 2013), it is important to study how these lakes are changing with respect to the glaciers. The CV also extends into the Puno region of Peru, but predominantly provides water to the Cusco region.

We also investigated snow-line changes for the QIC. Tropical glaciers behave differently than high-latitude glaciers, and the automated methods previously used to delineate the snow line or equilibrium line altitude (ELA) in other regions globally (Hall et al., 1987; Bronge and Bronge, 1999; Mathieu et al., 2009; Yu et al., 2012) have proven unsuccessful in our study region. In an effort to determine a consistent automated algorithm to delineate the snow line and differentiate between snow and ice on the glaciers, this study follows on from methodology suggested for this region by Klein and Isacks (1999) relying on spectral unmixing to investigate snow-line changes for the QIC.

Using the 158 multi-spectral satellite images, we (1) preprocessed the imagery (georeferenced and co-registered), (2) applied various classification methods to the imagery to delineate glacial and lake area outlines best, and (3) used spectral unmixing to distinguish between snow and ice on a glacier to approximate the change in the snow line of the QIC over time. Our results can ultimately be incorporated into the Global Land Ice Measurements from Space (GLIMS) database, and used by those seeking a more comprehensive 
understanding of glacial and lake area changes in this region over the past $\sim 37$ years.

\section{Geographic and climatic setting of the study site}

The CV and the QIC are located in the central Andes in southeastern Peru (Fig. 1) - specifically, in the southern portion of the eastern branch (Cordillera Oriental) of the Peruvian Andes (Hastenrath, 1998). We have used the general geographic definition of the $\mathrm{CV}$ as provided by Morales Arnao (1998), and in this study we refer to this as the entire CV study area. The CV mountain range is among the highest in Peru, with the highest peak (Nevado Ausangate) at $6384 \mathrm{~m}$ a.s.l. (above sea level), and glaciers terminating around $4700-5000 \mathrm{~m}$ a.s.l. (Salzmann et al., 2013). Climatically, the $\mathrm{CV}$ region experiences two distinct seasons - a wet and warm $\left(1-2{ }^{\circ} \mathrm{C}\right.$ higher) season during the austral summer (October/November to March/April) and a dry and cold season (April/May to September/October) (Rabatel et al., 2013). As a result, most of the precipitation falls during the warm/wet season. Ablation occurs year-round due to high solar radiation at these latitudes, but is reduced during the dry/cold season due to enhanced sublimation (Rabatel et al., 2012; Vuille et al., 2008b). Additionally, on interannual timescales, the El Niño-Southern Oscillation (ENSO) is reported to have a significant influence on the climate variability in this region (Rabatel et al., 2013; Vuille et al., 2008a; Albert, 2007; Perry et al., 2013; Thompson et al., 2013; Morales et al., 2012), with La Niña years tending to be cooler and wetter, and El Niño years tending to be warmer and drier (Vuille et al., 2008a; Rabatel et al., 2013). How this affects glacier mass balance in the $\mathrm{CV}$, however, has yet to be systematically investigated. The regions in southeastern Peru are characterized by a very steep precipitation gradient and orographic rainfall effect created by the eastern Andean slopes (Bookhagen and Strecker, 2008, 2012) (Fig. 1c), ranging from $>3 \mathrm{~m} \mathrm{yr}^{-1}$ annual rainfall at the mountain front to $<0.25 \mathrm{~m} \mathrm{yr}^{-1}$ rainfall on the high-elevation, arid Altiplano.

\section{Data sources}

To create our glacial and lake area inventory, we used a variety of optical and multi-spectral satellite imagery, including Landsat Multispectral Scanner (MSS), Thematic Mapper (TM) and Enhanced Thematic Mapper Plus (ETM+), Advanced Spaceborne Thermal Emission and Reflection Radiometer (ASTER), and declassified Corona KH-9 imagery. The characteristics of each of these sensors can be found in Table 1, and an example of each of these images can be seen in Fig. 2.

We have obtained a total of 121 usable Landsat images (6 MSS from 1975 to 1985,108 TM from 1985 to 2011, 7 ETM+ from 1999 to 2003), 36 ASTER images (from 2001 to 2012), and $1 \mathrm{KH}-9$ Corona image from 1980, resulting

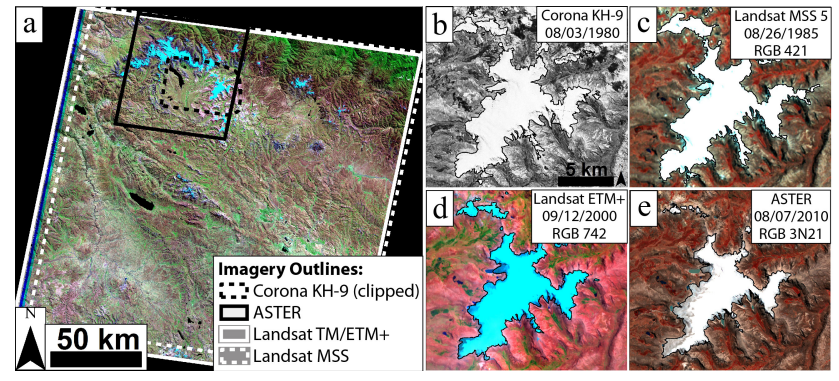

Fig. 2. Overview of imagery used in this study (see Fig. 1 for location). (a) Landsat ETM+ image from 24 June 2000 (base image) showing bands $742 \mathrm{RGB}$ with the outlines of the other imagery coverage areas. The QIC is shown in panels (b)-(e) to illustrate the various types of imagery. The black line outlines the QIC extent in each image. Note the areal extent changes between 1980 and 2010. In our study, we have used the outlines in (b) and (e), but not (c) or (d) because there appears to be snow in these images.

in a total of 158 images dating from 1975 to 2012 (a complete list of images used can be found in Table S1 of the Supplement). All 158 images were used to create a lake area time series, although not every lake was outlined in each image due to clouds or the occasional difficulty in classifying a specific lake; 69 images (56 Landsat, 1 Corona, and 12 ASTER) were used to create the glacial area time series, with images containing a range of 1 to all (10 identified) of the glacierized regions located within this Landsat TM/ETM+ scene (Fig. 2a). Similar to the lakes, not all images could be used for all glacierized regions due to classification problems. Specifically for this area, obstruction by cloud cover limits the images that can be used during the cold/dry season (Rabatel et al., 2012). Also, storms producing transient snow cover still occur during the dry season, and this local/regional snow can prevent obtaining accurate glacierized region outlines. For this reason, we have only used images, or parts of images (as this snow is often localized), where no transient snow cover is visible.

In addition to the multi-spectral satellite imagery, this study used the 2000 Shuttle Radar Topography Mission (SRTM) digital elevation model (DEM) (version 4). Acquired within 11 days during February 2000, this mission provided near-global $\left(\sim 60^{\circ} \mathrm{N}\right.$ to $56^{\circ} \mathrm{S}$ latitude) digital elevation data at a horizontal resolution of $\sim 90 \mathrm{~m}$ (Farr et al., 2007). Linear vertical absolute and relative height errors are less than $16 \mathrm{~m}$ and $10 \mathrm{~m}$ respectively, decreasing to $6.2 \mathrm{~m}$ and $5.5 \mathrm{~m}$ respectively for South America (Farr et al., 2007). For this study, these data were resampled to $15 \mathrm{~m}$ using bilinear interpolation. We also worked with the ASTER Global Digital Elevation Model (GDEM V1 and V2), a DEM created from ASTER imagery taken over the course of a decade. Since glacial elevations are likely to change over 10 year time periods, inconsistencies over glaciers and shadowing effects from topography and clouds prevented us from using the ASTER GDEM. 
Table 1. Characteristics of the satellites and sensors used in this study. Bands in italics are those that have not been used. Data sources are as follows: Corona (Surazakov and Aizen, 2010), Landsat (http://landsat.gsfc.nasa.gov/about/technical.html), ASTER (http://asterweb.jpl.nasa. gov). Table modified after Svoboda and Paul (2009).

\begin{tabular}{|c|c|c|c|c|c|c|}
\hline & Corona KH-9 & Landsat MSS (1-3) & Landsat MSS (4-5) & Landsat TM & Landsat ETM+ & ASTER \\
\hline $\begin{array}{l}\text { Date Range of } \\
\text { Images Used }\end{array}$ & 1980 & 1975 & $1982-1985$ & $1985-2011$ & $1999-2003$ & $2001-2012$ \\
\hline $\begin{array}{l}\text { No. of Images: } \\
\text { Total (\& Lakes) }\end{array}$ & 1 & 3 & 3 & 108 & 7 & 36 \\
\hline $\begin{array}{l}\text { No. of Images: } \\
\text { Glaciers }\end{array}$ & 1 & 2 & 1 & 52 & 1 & 12 \\
\hline $\begin{array}{l}\text { Path/Row of } \\
\text { Images Used }\end{array}$ & Mission 1216 & $002-003 / 070$ & $003 / 070$ & $003 / 070$ & $003 / 070$ & multiple \\
\hline Band: Wavelengths $(\mu \mathrm{m})$ & - & - & - & $1: 0.45-0.52$ & $1: 0.45-0.52$ & - \\
\hline Visible: & $\begin{array}{l}\text { Unknown } \\
- \\
-\end{array}$ & $\begin{array}{l}\text { 4: } 0.5-0.6 \\
5: 0.6-0.7 \\
-\end{array}$ & $\begin{array}{l}1: 0.5-0.6 \\
2: 0.6-0.7 \\
-\end{array}$ & $\begin{array}{l}\text { 2: } 0.52-0.60 \\
\text { 3: } 0.63-0.69 \\
-\end{array}$ & $\begin{array}{l}\text { 2: } 0.52-0.60 \\
\text { 3: } 0.63-0.69 \\
\text { 8: } 0.52-0.90 \text { (VNIR panchro.) }\end{array}$ & $\begin{array}{l}1: 0.52-0.60 \\
2: 0.63-0.69 \\
-\end{array}$ \\
\hline Near-IR: & - & 6: $0.7-0.8$ & 3: $0.7-0.8$ & 4: $0.76-0.90$ & 4: $0.77-0.90$ & 3N/B: $0.76-0.86$ (Nadir \& Back) \\
\hline & - & 7: $0.8-1.1$ & 4: $0.8-1.1$ & - & - & - \\
\hline Shortwave IR: & - & - & - & 5: $1.55-1.75$ & 5: $1.55-1.75$ & 4: $1.60-1.70$ \\
\hline Thermal IR: & $\begin{array}{l}- \\
-\end{array}$ & $\begin{array}{l}- \\
-\end{array}$ & $\begin{array}{ll}- \\
-\end{array}$ & $\begin{array}{l}7: 2.08-2.35 \\
6: 10.40-12.50\end{array}$ & $\begin{array}{l}7: 2.08-2.35 \\
6: 10.40-12.50\end{array}$ & $\begin{array}{l}\text { 5-9: } 2.145-2.430 \text { ( } 5 \text { bands }) \\
\text { 10-14: } 8.125-11.65 \text { ( } 5 \text { bands })\end{array}$ \\
\hline Spatial Resolution (m) & $6-9 \mathrm{~m}$ & $68 \times 83 *$ & $68 \times 83 *$ & $\begin{array}{l}1-5 \& 7: 30 \\
6: 120\end{array}$ & $\begin{array}{l}1-5 \& 7: 30 \\
6: 60 \\
8: 15\end{array}$ & $\begin{array}{l}\text { 1-3: } 15 \\
\text { 4-9: } 30 \\
10-14: 90\end{array}$ \\
\hline Image Size (km) & $250 \times 125$ & $185 \times 185$ & $185 \times 185$ & $\sim 170 \times 183$ & $\sim 170 \times 183$ & $\sim 60 \times 60$ \\
\hline $\begin{array}{l}\text { Temporal Resolution } \\
\text { (days) }\end{array}$ & - & 18 & 16 & 16 & 16 & 16 \\
\hline Orbit & - & $\begin{array}{l}\text { polar, sun- } \\
\text { synchronous }\end{array}$ & $\begin{array}{l}\text { polar, sun- } \\
\text { synchronous }\end{array}$ & $\begin{array}{l}\text { polar, sun- } \\
\text { synchronous }\end{array}$ & $\begin{array}{l}\text { polar, sun- } \\
\text { synchronous }\end{array}$ & $\begin{array}{l}\text { polar, sun- } \\
\text { synchronous }\end{array}$ \\
\hline Altitude (km) & 171 & 900 & 900 & 705 & 705 & 705 \\
\hline Inclination $\left({ }^{\circ}\right)$ & 96.5 & 99.2 & 99.2 & 98.2 & 98.2 & 98.3 \\
\hline Comments & & $\begin{array}{l}\text { * commonly resampled } \\
\text { to } 60 \mathrm{~m}\end{array}$ & $\begin{array}{l}* \text { commonly resampled } \\
\text { to } 60 \mathrm{~m}\end{array}$ & $\begin{array}{l}\text { Stopped acquiring } \\
\text { images in November } 2011\end{array}$ & $\begin{array}{l}\text { Scan Line } \\
\text { Corrector failure in May } 2003\end{array}$ & $\begin{array}{l}\text { SWIR failure (anomalous } \\
\text { saturation) in May } 2007\end{array}$ \\
\hline
\end{tabular}

\section{Methodology}

The creation of lake, glacier, and snow-line outlines are multi-step processes with some manual intervention. Upon acquisition, and before classification, the images require initial pre-processing and calibration. This involves georeferencing (Corona, ASTER), pan-sharpening (base-image only), resampling if necessary (ASTER shortwave infrared (SWIR) $30 \mathrm{~m}$ to $15 \mathrm{~m}$ so that the different bands with different spatial resolutions can be merged), conversion to reflectance (all ASTER images, and Landsat images used for snow-line analysis, converted to reflectance using standard techniques), and aligning to the base image (all images). For this study, a Landsat ETM+ image from 24 June 2000 (path 003, row 070, Fig. 2a) was chosen as the base image as this image covered the entire study region with no clouds and good gain control, important factors when aligning images or calibrating images for reflectance. We specifically used a Landsat ETM+ image for this, as Masek et al. (2001) report that Landsat ETM+ has decreased noise levels and increased radiometric precision compared to Landsat TM 5.

The general process used to classify the images is outlined in Fig. 3. Upon completion of pre-processing, the first step was to classify the lakes in each image, i.e., to create a lake mask (Sect. 4.1). This was done using simple band ratios and filtering, removal of shadows using a hillshade

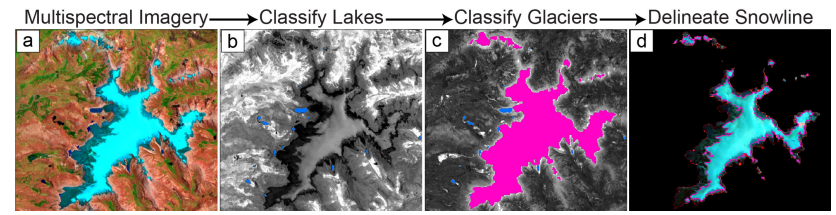

Fig. 3. Flow chart indicating the general methodology used, applied to a Landsat TM image from 15 October 2009. The images (a) are used to classify lakes (b) using a normalized difference water index (NDWI) algorithm (lakes: blue). Glaciers (c) are then classified using a TM3/TM5 \& TM1 algorithm (Landsat TM/ETM+) and clipping of the data with the previously created lake mask to remove incorrectly classified lakes (shown on TM3/TM5 image - lakes: blue, QIC: pink). The QIC (or other glacier) outline is then used to clip calibrated reflectance data (d) to obtain snow-line information for that area alone using MESMA. See text for abbreviation explanations.

mask for each image, followed by manual editing (Huggel et al., 2002). Glaciers were classified similarly using simple ratios (Svoboda and Paul, 2009) (Sect. 4.2). Subsequently, the previously created lake mask was applied to the resulting glacier mask, to remove incorrectly classified lakes. Manual editing and validation was a required final step. In determining the snow line for a particular glacier (Sect. 4.3), a calibrated reflectance image was first clipped to the glacier extent 


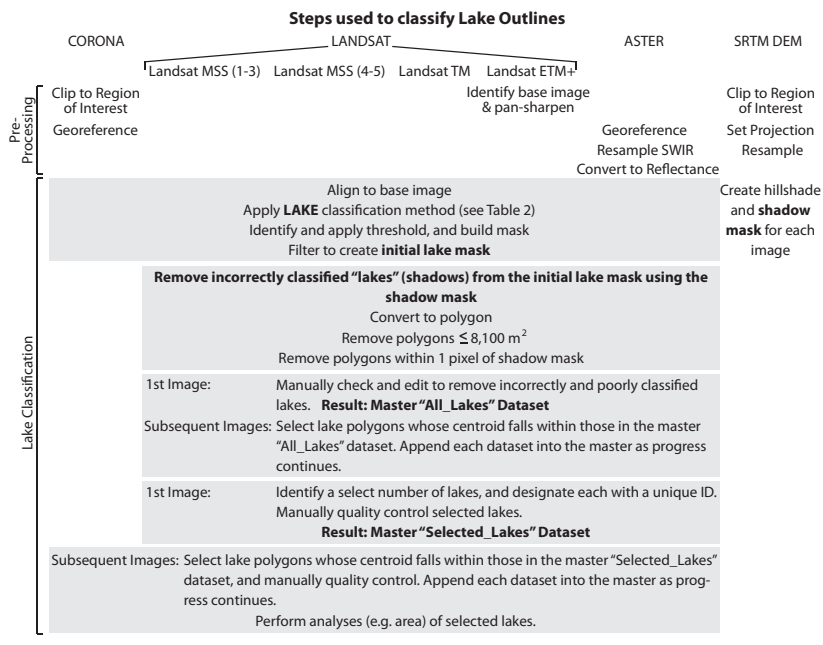

Fig. 4. Steps summarizing the processes used to classify lake outlines, including pre-processing steps. Grey background overlaps those data sets to which each process applies, and bold text indicates important steps or data sets (either complete, or to be used in subsequent processing).

using this glacier mask. After selecting snow and ice regions, we then performed a multiple endmember spectral mixture analysis (MESMA) (Klein and Isacks, 1999; Roberts et al., 1998). To create files usable in further analysis, all rasters are converted to polygons.

\subsection{Lake area mapping}

The steps involved in the lake classification of each group of imagery are summarized in Fig. 4 and outlined in detail in Supplement B1 (and Fig. S1).

Lakes in glacial regions often have a variety of biological and physical components (e.g., pollen and sediment) influencing their color, and the employed methodology must be able to distinguish varying colors. For the Landsat TM/ETM+ imagery we pursued the methodology outlined in Huggel et al. (2002) using a normalized difference water index (NDWI: Landsat bands (TM4-TM1)/(TM4+TM1)) followed by a hillshade mask. This NDWI performed well, based on the classified outline corresponding closely to the visual lake outline, and allows classification of lakes with a range of suspended sediment concentrations. ASTER images were processed in the same fashion as the Landsat TM/ETM+ images. However, lake detection proved to be more complicated due to the lack of a "blue" band (0.45$0.52 \mu \mathrm{m}$, equating to Landsat B1, see Table 1) in the ASTER images. Previous studies have used the green band as an alternative, resulting in an approximation of the NDWI algorithm using (AST3-AST1)/(AST3+AST1) (Bolch et al., 2008). While this index performed fairly well in identifying lakes with higher concentrations of suspended sediment (typically found in close proximity to glaciers), it was unable to capture lakes with lower concentrations of suspended sediment successfully. To classify lower sediment content lakes, a threshold in ASTER B3 proved successful, but alternatively was not always successful at identifying the higher sediment content lakes. A combination of both the ASTER NDWIapproximation algorithm and ASTER B3 provided the most suitable method to identify lakes with the greatest range of suspended sediment concentrations. Unfortunately, this combination method could not identify all lakes throughout the study region. Figure 5 outlines the method used to classify lakes in the ASTER imagery, illustrating where each method works and does not work.

After initial classification and filtering, shadows were removed using a hillshade mask and some manual editing, resulting in a master-lake file containing only lakes for each image. We then selected, and manually quality controlled, fifty lakes that were typically well classified (large and small, high and low sediment concentrations, near and far from glaciers, downstream from glacial watersheds and removed from glacial watersheds, comprising a range of lakes). Using the SRTM DEM, we have delineated the watersheds or catchment boundaries for each of these fifty lakes using standardGIS flow accumulation procedures. The methods, thresholds and filters used in the classification of lakes and glaciers for each data set are summarized in Table 2.

\subsection{Glacier area mapping}

Debate continues on the best method to be used for delineating glacial outlines, with different studies suggesting different methods as superior (Paul and Kääb, 2005; Racoviteanu et al., 2008b, 2009). The consensus that seems to have been reached is that it depends on the test site in question. Manual delineation is very time consuming and can be highly subjective and variable depending on the classifier, and as a result, automated thresholds are recommended (Paul et al., 2013). Band ratios and thresholds also provide the best compromise between processing time and accuracy, with an estimated accuracy difference of $<3 \%$ between the three most often used techniques: Landsat bands $3 / 5,4 / 5$, and the Normalized Difference Snow Index (Albert, 2002). Given that within Peru there is no "standard" for remotely sensed classification of glacier outlines, in our study, we followed the methodology and thresholds outlined in Svoboda and Paul (2009) using Landsat (TM/ETM+) bands 3/5 and ASTER bands 3/4, followed by a threshold in Landsat and ASTER bands 1 to include snow and ice in cast shadow. Their MSS classification scheme worked poorly for our images, and so we classified the glacierized areas in the MSS images using a singleband thresholding process. The glaciers in the Corona and ASTER images lacking SWIR bands were manually delineated. Not all images are suitable for glacier classification (local/regional snow cover or clouds obscuring outlines). In order to gain as much information as possible on how the glacierized regions behave on an annual as well as a decadal 


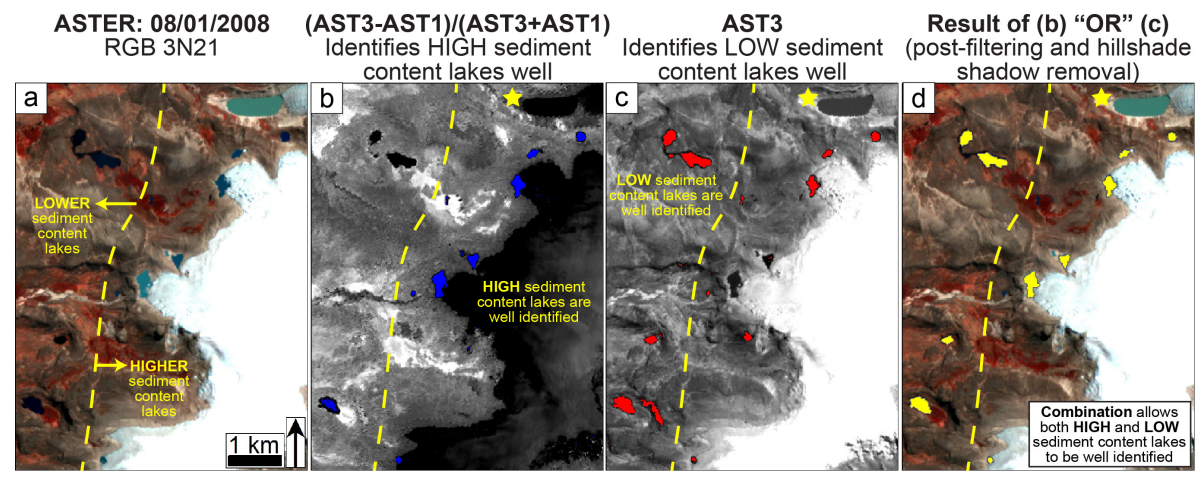

Fig. 5. ASTER image illustrating how lakes of both high- and low-sediment concentrations were classified in this study. (a) highlights part of the western QIC where lakes of differing sediment contents exist, (b) shows the results of the (AST3-AST1)/(AST3+AST1) ratio (blue pixels: <-0.25), (c) shows ASTER B3 (red pixels: $\leq 1000)$, and (d) illustrates the final result when a combination of both methods are used. Note that none of these methods provide a perfect classification, and some lakes remain unidentified (the yellow star indicates the proglacial lake of Qori Kalis glacier and is unclassified using these methods). Yellow dashed line indicates the approximate line of separation between higher and lower sediment content lakes, which is roughly related to distance from the QIC.

Table 2. Summary of methods and thresholds used in lake and glacier classifications. The threshold for shadows in the hillshades (HS) was DN < 70 for all images. DN represents digital number; CF and MF with their kernel sizes stand for closing filter and median filter, respectively.

\begin{tabular}{|c|c|c|c|c|c|c|c|c|}
\hline \multirow[b]{2}{*}{ Sensor } & \multicolumn{5}{|c|}{ Lakes } & \multicolumn{3}{|c|}{ Glaciers } \\
\hline & Method & Thr & shold (mean, median, mo & de) & Filtering & Method & Threshold & Filtering \\
\hline Corona & Manual & - & - & - & - & Manual & - & - \\
\hline Landsat MSS (1-3) & $\begin{array}{l}\text { (MSS7-MSS4)/(MSS7+MSS4), } \\
\text { and HS }\end{array}$ & $<-0.17$ & $<-0.25$ & $<-0.25$ & CF- $5 \times 5$ & Density slice & DN 105-255 (MSS6) & $\mathrm{MF}-3 \times 3$ \\
\hline Landsat MSS (4-5) & $\begin{array}{l}\text { (MSS4-MSS1)/(MSS4+MSS1), } \\
\text { and HS }\end{array}$ & $<-0.08$ & $<0.00$ & $<0.00$ & $\mathrm{CF}-5 \times 5$ & Density slice & DN 165-255 (MSS1) & $\mathrm{MF}-3 \times 3$ \\
\hline Landsat TM & NDWI, and HS & $<-0.51$ & $<-0.50$ & $<-0.50$ & $\mathrm{CF}-5 \times 5$ & TM3/TM5 \& TM1 & $\geq 2.0 \&>25$ & $\begin{array}{l}\mathrm{MF}-3 \times 3 \\
\& \mathrm{CF}-5 \times 5\end{array}$ \\
\hline Landsat ETM+ & NDWI, and HS & $<-0.39$ & $<-0.40$ & $<-0.40$ & CF- $5 \times 5$ & ETM3/ETM5 \& ETM1 & $\geq 2.0 \&>25$ & $\begin{array}{l}\text { MF- } 3 \times 3 \\
\& \text { CF- } 5 \times 5\end{array}$ \\
\hline ASTER (w/ SWIR) & $\begin{array}{l}(\mathrm{AST} 3-\mathrm{AST} 1) /(\mathrm{AST} 3+\mathrm{AST} 1) \\
\mathrm{OR} \text { AST } 3 \text {, and } \mathrm{HS}\end{array}$ & $<-0.24 \mathrm{OR} \leq 1000$ & $<-0.25 \mathrm{OR} \leq 1000$ & $<-0.25 \mathrm{OR} \leq 1000$ & $\mathrm{CF}-3 \times 3$ & AST3/AST4 \& AST1 & $\geq 1.6 \&>47$ & $\mathrm{MF}-3 \times 3$ \\
\hline ASTER (w/o SWIR) & $\begin{array}{l}(\mathrm{AST} 3-\mathrm{AST} 1) /(\mathrm{AST} 3+\mathrm{AST} 1) \\
\text { OR AST } 3 \text {, and } \mathrm{HS}\end{array}$ & $<-0.24 \mathrm{OR} \leq 1000$ & $<-0.25 \mathrm{OR} \leq 1000$ & $<-0.25 \mathrm{OR} \leq 1000$ & $\mathrm{CF}-3 \times 3$ & Manual & - & - \\
\hline
\end{tabular}

timescale, we have classified all images where ice is visible at the glacial boundary, no snow patches exist beyond the extent of the glacierized region, and cloud cover does not occlude any part of the glacial boundaries. The general steps involved in the glacier classification of each group of imagery are summarized in Fig. 6 (and Fig. S1 in the Supplement), with the methods and thresholds used for each set of imagery summarized in Table 2 .

Upon creation of the initial glacier mask, postclassification and filtering, the previously created lake masks for each image were applied to each glacier mask to remove incorrectly classified lake pixels. Subsequently, polygons with areas $\leq 10000 \mathrm{~m}^{2}$ (corresponding to $11,44,2$, and 123 pixels for Landsat TM/ETM+, ASTER, Landsat MSS and Corona, respectively) were removed (as recommended by Paul et al., 2009), as were any remaining lake polygons that the lake mask did not capture. Using the earliest usable image for each area, we identified and assigned a unique ID to discrete glacierized areas (closed ice masses or polygons that are nearby or that appeared to be part of that same glaciated mass) throughout the Landsat TM/ETM+ scene extent encompassing the entire CV area. Working in chronological order from 1975 to 2010, these IDs were assigned to polygons falling within those of their earliest outline (the assumed largest glacierized area). Similar to Salzmann et al. (2013), we have not separately mapped debris-covered glaciers as these areas are expected to be minimal in this region. A more detailed description of the glacier classification process can be found in Supplement B2. In addition to analyzing these 10 glacierized units as a whole, we have also delineated the individual glacial basins within these larger units using standard-GIS flow accumulation procedures as we have done for the lakes.

\subsection{Snow-line mapping}

On some images from the mid- to late dry/cold season, the snow lines are clearly visible. Classifying these snow lines using an automated algorithm, however, proved more complicated than expected. Many of the suggested methods proved unsatisfactory, and no single method allowed 


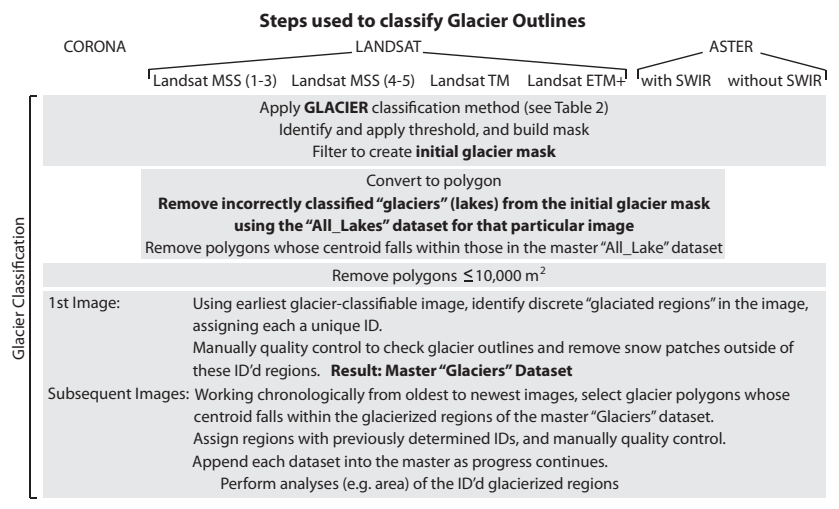

Fig. 6. Steps summarizing the processes used to classify glacial outlines. As with Fig. 4, grey background overlaps those data sets to which each process applies, and bold text indicates important steps or data sets.

successfully classifying snow lines in all imagery for this region, for example, Landsat TM bands 4/5 (Hall et al., 1987), Landsat TM bands $3 / 4$ and $3 / 5$, and maximum likelihood classification of principal components (Bronge and Bronge, 1999), maximum likelihood classification of principal components on ASTER imagery (Mathieu et al., 2009), and a two-step unsupervised classification process based on Landsat ETM+ bands and algorithms and snow/ice texture (Yu et al., 2012). While Rabatel et al. (2005) manually delineated the ELA on three glaciers in the French Alps, we pursued the methodology suggested by Klein and Isacks (1999) for the Zongo Glacier in Bolivia and the QIC: spectral mixture analysis (e.g., Painter et al., 1998). Spectral unmixing has also been successfully used by Chan et al. (2009) in delineating the snow line and the area accumulation ratio for the Morteratsch glacier in Switzerland. In our study, we focus on the QIC, initially creating a spectral library of snow and ice endmembers from the images. A small selection of these spectra were used to unmix the ice cap spectrally and delineate the snow line using multiple endmember (snow, ice, and shadow) spectral mixture analysis (MESMA). The resulting classification identifies pixels that contain varying percentages of snow and ice, allowing for classification of regions that are dominantly snow (accumulation zone) or dominantly ice (ablation zone). We have performed this methodology (Fig. 7) on three images between 1988 and 2009 for the QIC.

The three images were first converted to reflectance and calibrated to the reflectance of the base image. After selecting representative endmember regions in each image, we used techniques described in Roberts et al. (2007) to create spectral libraries for each, and subsequently to identify optimum spectra for these endmembers, specifically using the metrics CoB (count-based endmember selection), EAR (endmember average RMSE), and MASA (minimum average spectral angle). The resulting spectra (Fig. S2), with their strong spectral

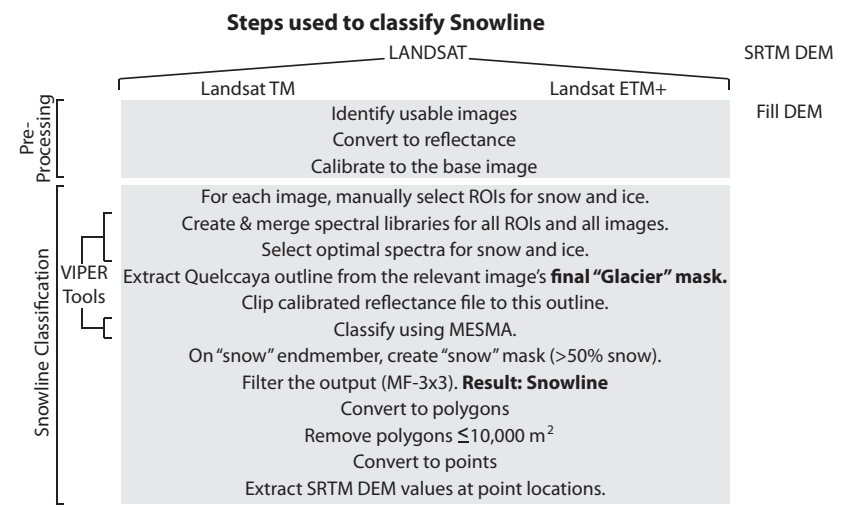

Fig. 7. Steps summarizing the processes used to classify glacier snow lines (specifically the QIC in this study). As with Figs. 4 and 6 , grey background overlaps those data sets to which each process applies, and bold text indicates important steps or data sets.

differences between snow and ice that make this method robust, were then run on each snow-line image using MESMA. As with the lake and glacier classifications, more information on the snow-line classification can be found in Supplement B3.

Post-MESMA processing includes applying a threshold to the snow endmember classification, where regions with snow (rather than ice) were determined to be in pixels $>50 \%$ snow (this threshold was determined by visual examination, and corroborates what is estimated in another study; Chan et al., 2009). After filtering, the outline of the accumulation area was converted to points and SRTM DEM values at those points extracted, to determine the elevation of the snow line.

\section{Results}

We first present our glacial results by focusing on the Quelccaya Ice Cap (Glacial ID 1), and then we expand to the Cordillera Vilcanota as a whole. Results for five different proglacial lakes follow, including four located along the western margins of the QIC, after which we present our snow-line estimates for the QIC. Figure 8 indicates the locations, extents, and names of the glacierized units and lakes investigated in this study. Additional glacial and lake area results can be found in Supplement C1 and C2, respectively.

\subsection{Glacier area changes}

\subsubsection{Quelccaya Ice Cap (QIC)}

Our results indicate that the QIC has decreased in area by $31 \%\left(19.4 \mathrm{~km}^{2}\right.$ ) over the time period 1980-2010 (Fig. 9). Using only the minimum area measurements for each year (which are best approximated for those years where multiple images and measurements exist), this represents an average decline rate of $0.57 \pm 0.10 \mathrm{~km}^{2} \mathrm{yr}^{-1}$ (all decline rate 


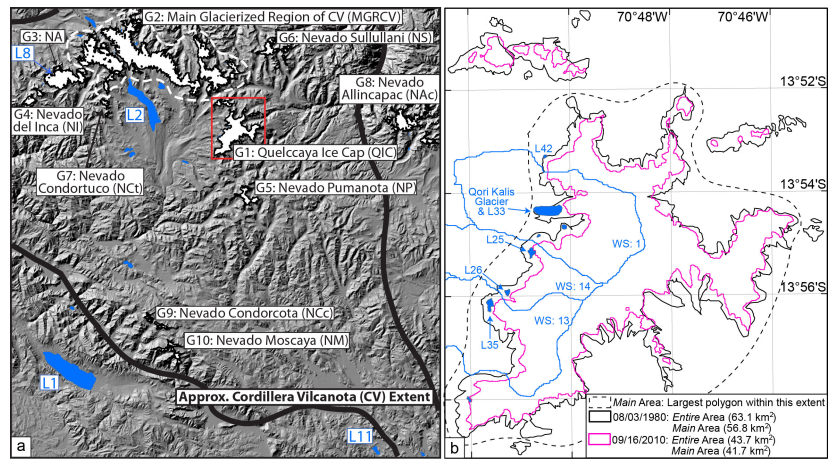

Fig. 8. (a) Hillshade topography showing the location of the identified glacierized regions $\left(\mathrm{G}^{n}\right)$ and lakes $\left(\mathrm{L}^{n}\right)$ for which results are presented in this study (including the Supplement). Glacierized regions are white (outlined by thin black lines), while lakes are blue (not all 50 lakes are shown here). All glacierized regions have been named after the dominant peak in that region, with the exception of G2, the extent of which is outlined by the dashed white line. The acronym NA for G3 stands for Nevado Ausangate. Additionally, the thick black line outlines the approximate extent of the Cordillera Vilcanota. Note that Nevado Allincapac (G8) is the only glacierized region located beyond the $\mathrm{CV}$. The red box outlines the extent of the QIC in (b), which shows the QIC's earliest and most recent glacial outlines and illustrates all polygons we have included in the QIC extent in this study (entire area) and also what we refer to as the main area. The locations of lakes for which results are presented in this study are indicated, as are three glacial watersheds within which these lakes are located.

uncertainties are $95 \%$ confidence intervals). This decline has not been constant; our time series indicates a period during the early to mid-2000s where glacial decline was low and glacial areas remained slightly higher than expected with respect to the multi-decadal decline rate. However, as a whole, the decline rates derived from our time series indicate that decline rates were higher during the period 2000-2010 than the period 1988-1999 (Table 3).

In calculating our glacial-area uncertainties (error bars), we assume that the error associated with area measurements is normally or Gaussian distributed. We first calculate the number of pixels comprising the area measurement outline using perimeter $(P)$ divided by grid-cell size ( $G$ - the largest spatial resolution (before resampling) of all bands used per image classification). This number is multiplied by 0.6872 $(1 \sigma)$ using the assumption that $\sim 69 \%$ of the pixels are subject to errors. Lastly, this number is multiplied by half of the area of a single pixel, assuming that the uncertainty for each pixel is not a full pixel but half a pixel, and is summarized as follows:

Error $(1 \sigma)=(P / G) \cdot 0.6872 \cdot G^{2} / 2$.

The resulting uncertainties are around $5 \%$, which is similar to comparison studies evaluating glacial-area delineation through remote-sensing methods (Paul et al., 2013), report-

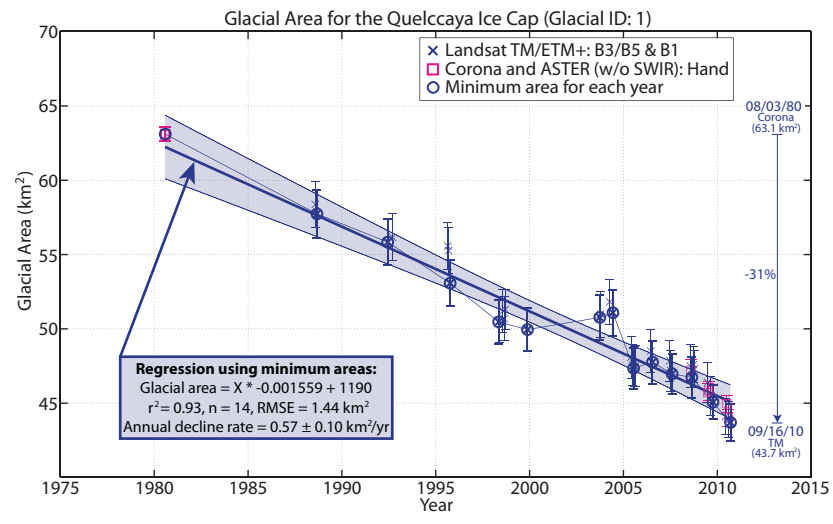

Fig. 9. Glacial-area time series for the Quelccaya Ice Cap (Glacial ID 1, Fig. 8). Symbols indicate image type and classification method. Bold and circled data points indicate the minimum area for that year (in some cases, the only area for that year). The regression uses only these minimum areas, and shading around regression outlines $95 \%$ confidence interval (same as uncertainties for the annual decline rates). Error bars are $1 \sigma$ uncertainties. Time series for each Glacial ID can be found in the Supplement (Figs. S3-S11).

ing errors $<5 \%$ for glaciers larger than $1 \mathrm{~km}^{2}$, and an overall error of $2-6 \%$ using automated methods.

\subsubsection{Cordillera Vilcanota $(\mathrm{CV})$}

Results for the Cordillera Vilcanota reflect that of the Quelccaya Ice Cap: glacierized areas have been significantly decreasing over the time period 1975-2010. In the 22 years between 1988 and 2010, all glacierized regions throughout the entire Cordillera Vilcanota (Glacial IDs 1-7, 9-10, but not ID 8) declined by a total of $107.6 \mathrm{~km}^{2}$ (30\% of 1988 extents, Fig. 10). Our findings are similar to those of Salzmann et al. (2013), although extents and time frames differ slightly between the two studies (Fig. 10).

To investigate changes in decline rates for the different glacial areas over different time periods, we have used the minimum areas for each year for each Glacial ID, normalizing the decline rates against their respective median areas (Table 3). We report four different time periods: 1975-2010 to include all imagery (including MSS), 1988-2010 to include the time period of the densest data set, 1988-1999 to approximate the 1990s, and 2000-2010 to span the first decade of the 2000s. Each of the glacierized regions within the $\mathrm{CV}$ (and just beyond) have declined at different rates. In general, for all time periods, smaller glacial areas are declining at a much faster rate than are larger glacial areas. For example, for the 1988-2010 time period, average decline rates for the smallest $\left(<\sim 10 \mathrm{~km}^{2}\right)$ glacial regions are approximately double $\left(27.8 \mathrm{~km}^{2} \mathrm{yr}^{-1} \mathrm{~km}^{-2}\right)$ that of the largest $\left(>\sim 20 \mathrm{~km}^{2}\right.$ ) glacial regions $\left(14.8 \mathrm{~km}^{2} \mathrm{yr}^{-1} \mathrm{~km}^{-2}\right)$, with the exception of the smallest (Glacial ID 10), which has a decline rate double that of the next smallest rate. In general, these 
Table 3. Normalized (against median area) glacial decline rates using minimum areas for each year for each Glacial ID throughout the Cordillera Vilcanota (IDs 1-7, 9-10) and just beyond (ID 8) for four different time periods: 1975-2010 (the whole time series, including Corona and MSS imagery), 1988-2010 (the densest time series, Landsat TM/ETM+ and ASTER), 1988-1999 (which roughly represents the 1990s but with additional 1988 data points to strengthen the regression), and 2000-2010 (the 2000s). CI is the confidence interval. For full Glacial ID names, please refer to Fig. 8. Note that decline rates are listed as positive values. These same decline rates before normalization can be found in the Supplement (Table S2).

\begin{tabular}{|c|c|c|c|c|c|c|c|c|c|c|c|c|c|c|c|c|c|}
\hline & \multirow[b]{2}{*}{ Glacier ID } & \multicolumn{4}{|c|}{ 1975-2010 } & \multicolumn{4}{|c|}{ 1988-2010 } & \multicolumn{4}{|c|}{ 1988-1999 } & \multicolumn{4}{|c|}{ 2000-2010 } \\
\hline & & $\begin{array}{c}\begin{array}{c}\text { No. } \\
\text { of } \\
\text { images }\end{array} \\
\end{array}$ & $\begin{array}{l}\text { Median area } \\
\left(\mathrm{km}^{2}\right)\end{array}$ & $\begin{array}{c}\text { Decline rate } \\
\pm 95 \% \mathrm{CI}\left(\times 10^{-3}\right. \\
\left.\mathrm{km}^{2} \mathrm{yr}^{-1} \mathrm{~km}^{-2}\right)\end{array}$ & $R^{2}$ & $\begin{array}{c}\text { No. } \\
\text { of } \\
\text { images }\end{array}$ & $\begin{array}{l}\text { Median area } \\
\left(\mathrm{km}^{2}\right)\end{array}$ & $\begin{array}{c}\text { Decline rate } \\
\pm 95 \% \mathrm{CI}\left(\times 10^{-3}\right. \\
\left.\mathrm{km}^{2} \mathrm{yr}^{-1} \mathrm{~km}^{-2}\right)\end{array}$ & $R^{2}$ & $\begin{array}{c}\text { No. } \\
\text { of } \\
\text { images }\end{array}$ & $\begin{array}{l}\text { Median area } \\
\left(\mathrm{km}^{2}\right)\end{array}$ & $\begin{array}{c}\text { Decline rate } \\
\pm 95 \% \mathrm{CI}\left(\times 10^{-3}\right. \\
\left.\mathrm{km}^{2} \mathrm{yr}^{-1} \mathrm{~km}^{-2}\right)\end{array}$ & $R^{2}$ & $\begin{array}{c}\begin{array}{c}\text { No. } \\
\text { of } \\
\text { images }\end{array} \\
\end{array}$ & $\begin{array}{l}\text { Median area } \\
\left(\mathrm{km}^{2}\right)\end{array}$ & $\begin{array}{c}\text { Decline rate } \\
\pm 95 \% \mathrm{CI}\left(\times 10^{-3}\right. \\
\left.\mathrm{km}^{2} \mathrm{yr}^{-1} \mathrm{~km}^{-2}\right)\end{array}$ & $R^{2}$ \\
\hline \multirow{11}{*}{ 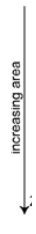 } & $10(\mathrm{NM})$ & 12 & 2.1 & $78.7 \pm 16.5$ & 0.91 & 11 & 2.1 & $65.7 \pm 30.0$ & 0.70 & 5 & 2.6 & $129.6 \pm 106.3$ & 0.78 & 6 & 1.5 & $137.5 \pm 64.0$ & 0.87 \\
\hline & $7(\mathrm{NCt})$ & 18 & 2.2 & $30.8 \pm 4.9$ & 0.91 & 17 & 2.2 & $33.2 \pm 8.3$ & 0.81 & 8 & 2.6 & $42.1 \pm 21.3$ & 0.76 & 9 & 2.0 & $43.3 \pm 22.9$ & 0.70 \\
\hline & $9(\mathrm{NCc})$ & 18 & 2.4 & $33.8 \pm 6.5$ & 0.87 & 16 & 2.4 & $31.9 \pm 9.7$ & 0.76 & 8 & 2.5 & $48.2 \pm 30.7$ & 0.66 & 8 & 1.9 & $51.1 \pm 24.3$ & 0.78 \\
\hline & $4(\mathrm{NI})$ & 14 & 4.6 & $28.7 \pm 5.3$ & 0.91 & 13 & 4.4 & $23.6 \pm 9.6$ & 0.70 & 5 & 5.0 & $37.1 \pm 33.7$ & 0.74 & 8 & 4.3 & $24.4 \pm 25.3$ & 0.39 \\
\hline & $5(\mathrm{NP})$ & & & & & 11 & 5.8 & $19.8 \pm 5.5$ & 0.87 & 5 & 6.7 & $27.0 \pm 12.2$ & 0.92 & 6 & 5.7 & $26.2 \pm 36.4$ & 0.37 \\
\hline & $6(\mathrm{NS})$ & 19 & 9.9 & $31.2 \pm 2.4$ & 0.98 & 17 & 9.4 & $30.6 \pm 4.2$ & 0.93 & 9 & 11.0 & $24.8 \pm 13.0$ & 0.70 & 8 & 7.3 & $52.0 \pm 8.1$ & 0.97 \\
\hline & $8(\mathrm{NAc})$ & 13 & 20.7 & $21.5 \pm 3.4$ & 0.94 & 12 & 20.4 & $22.7 \pm 6.7$ & 0.83 & 6 & 25.9 & $19.6 \pm 29.3$ & 0.32 & 6 & 19.4 & $20.6 \pm 22.1$ & 0.53 \\
\hline & 3 (NA) & 11 & 29.5 & $11.0 \pm 2.7$ & 0.89 & 10 & 29.3 & $10.9 \pm 4.9$ & 0.73 & 4 & 32.9 & $18.4 \pm 26.9$ & 0.72 & 6 & 28.9 & $22.7 \pm 15.8$ & 0.75 \\
\hline & 1 (QIC) & 14 & 50.2 & $11.3 \pm 1.9^{*}$ & 0.93 & 13 & 50.0 & $11.2 \pm 2.2$ & 0.91 & 5 & 53.1 & $13.8 \pm 3.1$ & 0.98 & 8 & 47.2 & $20.4 \pm 6.9$ & 0.88 \\
\hline & 2 (MGRCV) & 13 & 189.1 & $15.2 \pm 2.2$ & 0.95 & 12 & 189.0 & $14.3 \pm 3.7$ & 0.87 & 6 & 218.8 & $14.0 \pm 19.2$ & 0.38 & 6 & 181.7 & $23.5 \pm 10.8$ & 0.87 \\
\hline & $\mathrm{CV}(1-7,9-10)$ & & & & & 8 & 285.3 & $14.0 \pm 4.0$ & 0.91 & 3 & 329.0 & $17.2 \pm 75.7$ & 0.78 & 5 & 276.2 & $23.7 \pm 17.2$ & 0.82 \\
\hline
\end{tabular}

*1980 (not 1975)-2010 for QIC.

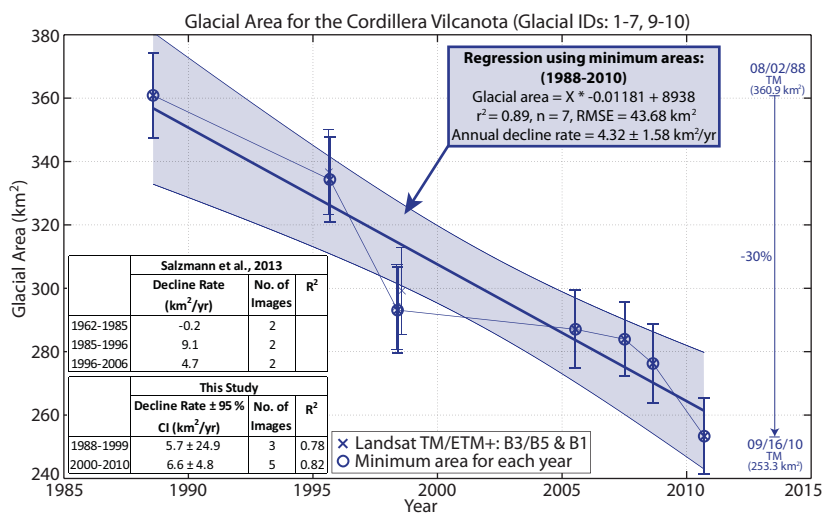

Fig. 10. Glacial-area time series for the Cordillera Vilcanota (Glacial IDs 1-7, 9-10 combined, Fig. 8) and decline rates for the CV from both this study and Salzmann et al. (2013). We do not include data points from Salzmann et al. (2013) as our glacial extents are not the same. However, we include decline rates derived from their study and our decline rates to show general comparisons, although these are non-normalized, and therefore reflect different areal extents. Note that because these are decline rates, they are listed as positive values. Hence, a negative value indicates advancement. Symbology and uncertainties are the same as for Fig. 9.

patterns persist through all time periods examined. Additionally, we also report mostly increasing decline rates during the 2000s over those of the 1990s (Table 3).

\subsection{Lake area changes}

Our lake area time series (1975-2012) includes 50 lakes (cf. Fig. 8). Here, we present the results of five proglacial lakes, all of which have formed after the Little Ice Age, specifically, since 1985. Lake ID 8 (Fig. 11) has formed downstream of Nevado Ausangate (Glacial ID 3), and Lake IDs 33 (a proglacial lake in front of Qori Kalis glacier, Fig. 12a), 25 and 26 (Fig. 12b), and 35 (Fig. 12c) have all formed along

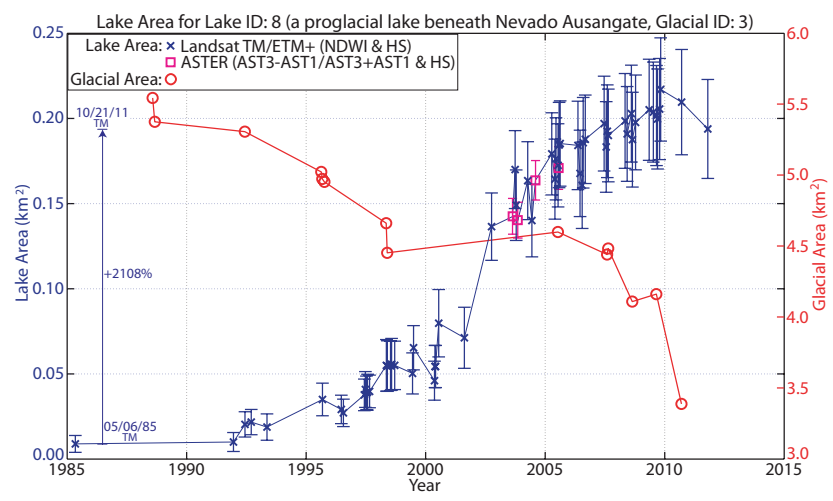

Fig. 11. Lake-area (blue) time series for Lake ID 8 (cf. Fig. 8) and glacial area (red) within its upstream catchment. This proglacial lake downstream of Nevado Ausangate (Glacial ID 3) started to rapidly grow in the late 1990 s and early 2000s. We do not show uncertainties in the glacial areas to avoid cluttering the figure, but these are on the order of $\sim 5 \%$.

the western margins of the QIC (Glacial ID 1). We present additional results for lake area changes in Supplement C2 (Figs. S15-S17).

Proglacial lake areas vary widely both temporally and spatially, reflecting a large number of processes that can control lake-area behavior, including glacial-melt processes, evaporation, groundwater infiltration, seepage, amongst others. To investigate lake area changes on a first-order level, we have investigated the lake-area changes of these five lakes in relation to their upstream glacial watersheds. Lake-area uncertainties have been calculated as for glacial-area uncertainties, following Eq. (1).

The proglacial Lake ID 8 beneath the Nevado Ausangate region did not exist before 1985 (Fig. 8a, Fig. 11). Since then, however, this lake has rapidly developed, beginning during the late 1990s but particularly during the early 2000s. Since the beginning of 2010, however, it appears that the lake 

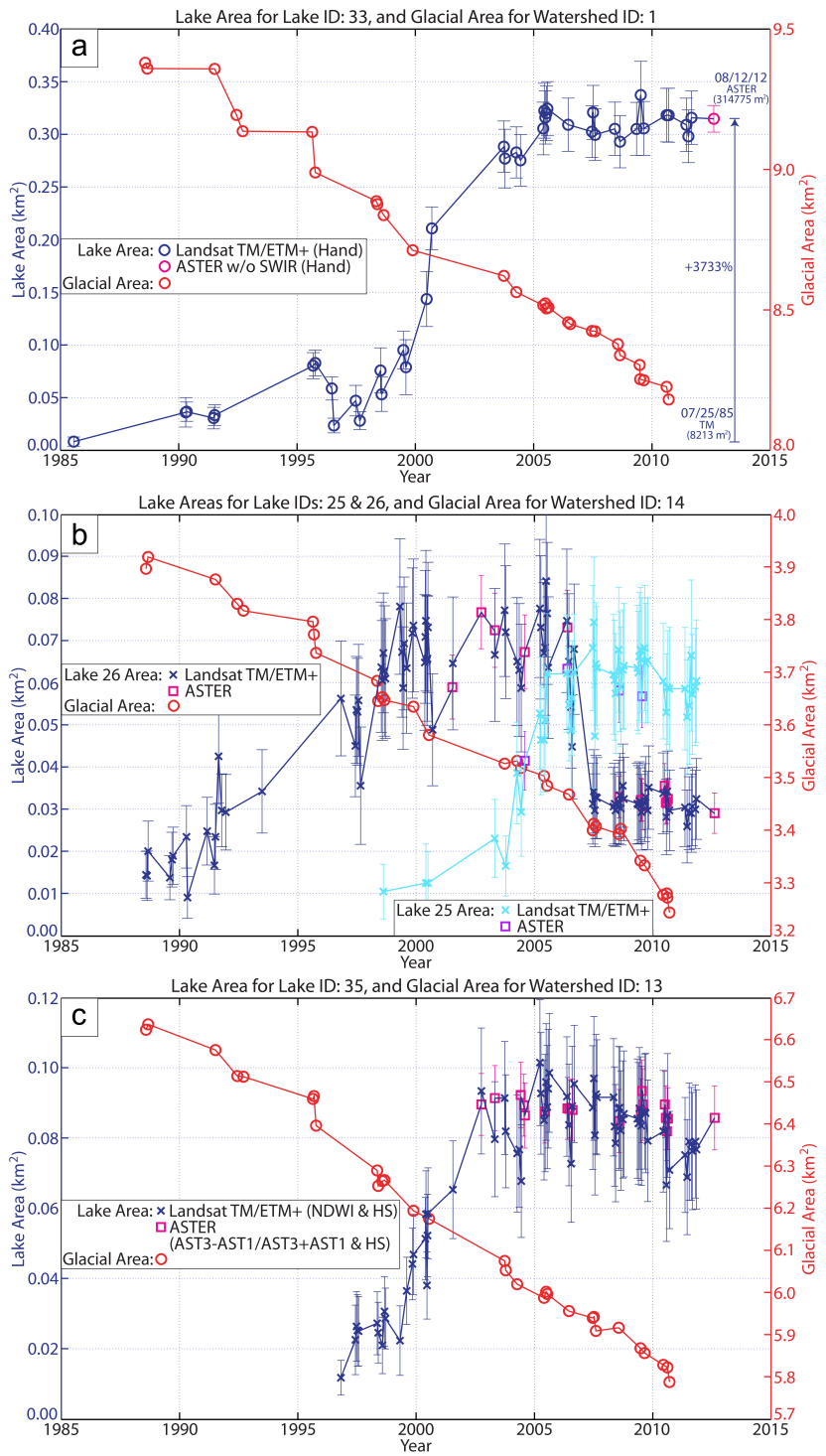

Fig. 12. Lake-area (blue) and glacial-area (red) time series for four proglacial lakes of the western QIC (Glacial ID 1). Locations of each lake and catchment can be found in Fig. 8b. (a) Lake ID 33, a lake in front of Qori Kalis glacier. Note that all area measurements of Lake ID 33 are hand-delineated, as this lake had a spectral signature that was not captured by any of the employed methodology (cf. Fig. 5). (b) Lake IDs 25 and 26, and (c) Lake ID 35. Notice that the majority of lake growth occurred during the late 1990s and early 2000s. We do not show uncertainties in the glacial areas $(\sim 5 \%)$ to avoid cluttering the figure.

area has begun to decline. Similar results can be seen for the proglacial lakes of the QIC (Fig. 12) with rapid increases in lake area during the late 1990s and early 2000s.

\subsection{Snow lines}

In this study, we used spectral unmixing methods to delineate transient snow-line elevations for the QIC for 3 years (1988,
1998, and 2009) using Landsat TM imagery. We report our results alongside those from previous studies (Table 4), but only minimal snow-line measurements exist in the literature, whether determined in situ or using remote sensing methods. With these snow lines we have calculated area accumulation ratios (AARs) for each of these measurements (Table 4). Between 1988 and 2009, the snow line of the QIC rose by $70 \mathrm{~m}$, corresponding to a decrease in AAR of $10 \%$. The snow line reached a maximum ( $\sim 5526$ m a.s.l.) during 1998, producing an unsustainable AAR of only $13 \%$. Our snow-line elevation errors appear to be large, but they reflect the snow-line altitude surrounding the entire QIC and are surprisingly robust.

\section{Discussion}

We first discuss our glacial-area changes, followed by lakearea and snow-line changes. We then provide a summary of our data and results. We emphasize problems and caveats when comparing glacial and lake area changes between different studies and methodologies.

\subsection{Glacier area changes}

\subsubsection{Quelccaya Ice Cap (QIC)}

In the previous section (Sect. 5.1.1) we illustrate the dramatic decline of the QIC (31\% between 1980 and 2010). Our results reflect those of Salzmann et al. (2013), who report a reduction in glacial area of $23 \%$ between 1985 and 2009 (we report a $22 \%$ decline between 1988 and 2009 - we do not provide a 1985 measurement). In general, our satellitederived glacial-area measurements correlate well with previous satellite estimates where boundary conditions were similar. However, comparing methodologies and glacial areas between studies is not always straightforward. Specifically, in the case of the QIC, it is evident that different studies use differing outlines for the extent of the QIC (Fig. 8b, Table 5). We use the term entire QIC to refer to all glacial regions identified in the earliest image (3 August 1980) and the term main QIC to identify the largest, continuous ice mass. Additionally, some studies (e.g., Hastenrath, 1998; Mark et al., 2002; Thompson, 1980) provide an area measurement merely informatively and tend to neglect providing the specific dates of the imagery (or methods) with which they determined the area. Other studies have investigated and reported the area of the QIC as part of their study, but provide less specific information on the extent of the QIC that was used (e.g., Albert, 2002, 2007) or the dates and imagery used (e.g., Salzmann et al., 2013). Comparing our results to those of other studies (Table 5), it appears that the majority of studies primarily use just the main QIC to determine the area, based on the fact that these results are closest to ours of the main QIC alone. This seems to be the case for Albert (2007), and while Salzmann et al. (2013) appear to use an extent that includes some 
Table 4. Glacial area, accumulation area, AAR (accumulation area ratio), and snow-line elevation for the QIC as reported in this and previous studies.

\begin{tabular}{lrrrrl}
\hline Date/year & $\begin{array}{r}\text { Glacial area } \pm 1 \sigma \\
\text { uncertainty }\left(\mathrm{km}^{2}\right)\end{array}$ & $\begin{array}{r}\text { Accumulation area } \pm 1 \sigma \\
\text { uncertainty }\left(\mathrm{km}^{2}\right)\end{array}$ & $\begin{array}{r}\text { AAR } \pm 1 \sigma \\
\text { uncertainty }(\%)\end{array}$ & $\begin{array}{r}\text { Snow-line elevation } \pm 1 \text { SD } \\
(\mathrm{m} \text { a.s.l. })\end{array}$ & Study \\
\hline$\sim 1962$ & 61 & - & 50 & 5275 & Hidrandina (1988) \\
$\sim 1976$ & 70 & - & - & 5300 & Mercer and Palacios (1977) \\
$\sim 1978$ & 55 & - & - & 5250 & Thompson (1980) \\
3 Sep 1988 & $57.7 \pm 1.6$ & $36.4 \pm 1.7$ & $63 \pm 5$ & $5344 \pm 93$ & This Study \\
30 Aug 1998 & $50.7 \pm 1.5$ & $6.8 \pm 0.4$ & $13 \pm 7$ & $5526 \pm 59$ & This Study \\
15 Oct 2009 & $45.1 \pm 1.2$ & $24 \pm 1.0$ & $53 \pm 5$ & $5414 \pm 73$ & This Study \\
\hline
\end{tabular}

outlying areas beyond the main QIC alone, they appear not to include the NW part of the ice cap - a part that was connected to the main part in 1975 but is since no longer connected. Our satellite-based measurements correspond fairly well with those from other studies (Table 5), and even where the extents may be different, the trends are comparable. We emphasize the consistency of our classification method, the large number of images used, and the long extent of the time series in this study and therefore suggest that our data are robust.

Additional discrepancies between glacial-area measurements are caused by the time of year the satellite image was taken. Determining whether snow is present at the glacial boundaries is done visually, and as such is subjective and dependent on the classifier. The data density of several reliable satellite images per year for some years allows us to see that even when the same classifier is used and only those images that appear snow-free are classified, intra-annual variability still exists (e.g., see Fig. S12 in the Supplement). Using the minimum areas out of these measurements best approximates the true minimum glacial extent for those years. We emphasize how important it is to give the date of measurement when reporting area results for glacierized regions because of intraannual variations and the difficulty in identifying an image where the glacial area is truly a minimum for that year.

Just as the QIC remains a classic and fairly well documented example of glacial retreat in this region, the Qori Kalis glacier in the QIC (cf. location in Fig. 8b) has been extensively field studied by Thompson and others over the past 3 decades (Brecher and Thompson, 1993; Thompson et al., 2006). We compare our satellite-derived glacial extents to field measurements for the Qori Kalis glacier (Thompson et al., 2006) (Fig. 13). While there are some discrepancies that are likely a result of measurements taken at different times of the year, the overall patterns match. Although our study does not have measurements for Qori Kalis dating back to 1963, the trends in the data are similar. Thompson et al. (2006) report a frontal retreat rate of $\sim 6 \mathrm{~m} \mathrm{yr}^{-1}$ for Qori Kalis during the 15 year period from 1963-1978, and a $\sim 10$ fold increase during the 14 years from 1991 to 2005 (a retreat rate of $\sim 60 \mathrm{~m} \mathrm{yr}^{-1}$ ). Our satellite-based study supports these findings, with a retreat rate of $\sim 9-10 \mathrm{~m} \mathrm{yr}^{-1}$ during

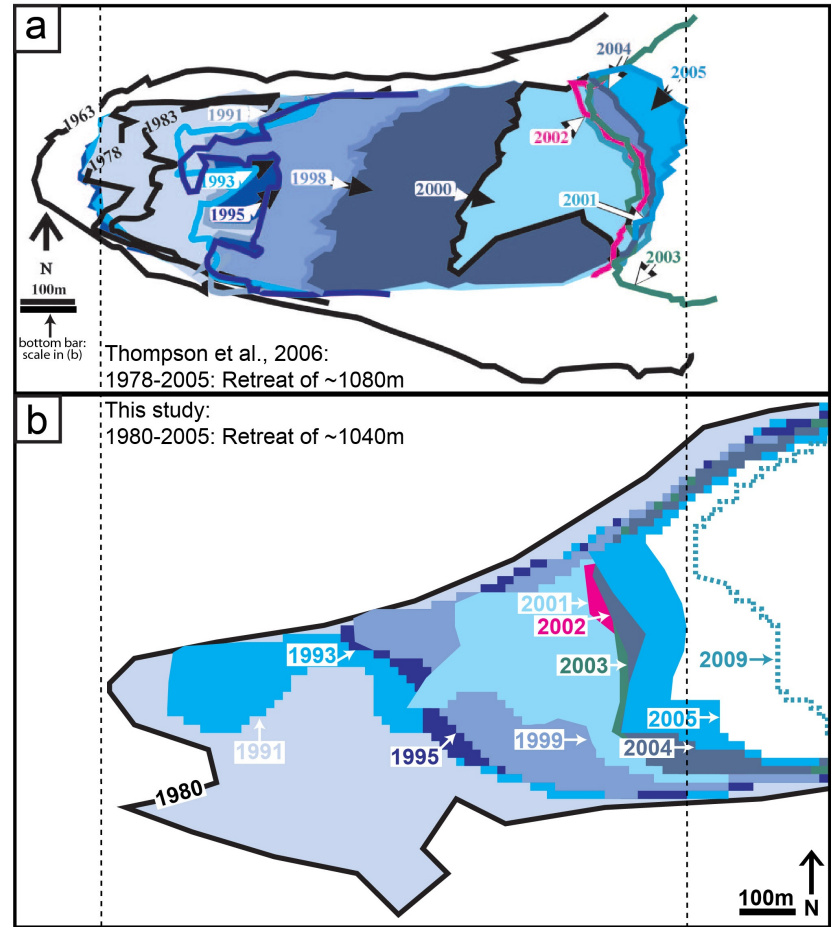

Fig. 13. Retreat of the Qori Kalis glacier in the QIC from (a) 1963 to 2005 (figure modified after Thompson et al., 2006) and (b) 1980 to 2009 (results from this study). This comparison shows fieldbased measurements (a) and our satellite-based measurements (b). Dashed lines are used for ease of viewing beginning and ending glacier extents in $\sim 1978$ and 2005 .

the shorter time period 1980-1991, but a similar retreat rate of $\sim 67 \mathrm{~m} \mathrm{yr}^{-1}$ during the subsequent 14 year period from 1991 to 2005 . This retreat is coeval with the development of the proglacial lake (Lake ID 33) shown in Fig. 12a.

\subsubsection{Cordillera Vilcanota $(\mathrm{CV})$}

As with the QIC, different studies use differing extents of the CV region. As previously mentioned in Sect. 2, our study uses the geographic definition as provided by Morales Arnao (1998) and incorporates this study's Glacial IDs 1-7 and 9-10. Glacial ID 8 is located beyond the CV and is not 
Table 5. Area measurements (including imagery used and date obtained) of the QIC from both this study and other studies. Entire QIC refers to all glacial regions identified in the earliest image, while main QIC refers to a subset of this, the largest continuous ice mass (cf. Fig. 8b). Our study has included the entire QIC area, i.e., all ice- and snow-covered regions that lie within the area of the earliest image (3 August 1980), and has captured smaller ice areas outside of the main QIC area.

\begin{tabular}{|c|c|c|c|c|c|c|c|}
\hline \multirow{3}{*}{ Year } & \multicolumn{3}{|c|}{ This study } & \multicolumn{4}{|c|}{ Other studies } \\
\hline & \multirow[t]{2}{*}{ Imagery (date) } & \multicolumn{2}{|c|}{ Area in $\mathrm{km}^{2}$} & Imagery (date) & \multicolumn{2}{|c|}{ Area in $\mathrm{km}^{2}$} & \multirow[t]{2}{*}{ Source } \\
\hline & & Entire QIC & Main QIC & & Entire QIC & Main QIC (assumed) & \\
\hline 1962 & & & & & 61.2 & & Hidrandina (1988) \\
\hline 1975 & & & & Landsat MSS (29 Jul 1975) & & 58.9 & Albert (2007) \\
\hline & & & & Landsat MSS (Unknown) & & 56.2 & Salzmann et al. (2013) \\
\hline 1980 & Corona KH-9 (3 Aug 1980) & 63.1 & 56.8 & Unknown & & 55.0 & Thompson (1980) \\
\hline 1985 & & & & Landsat TM (25 Jul 1985) & & 58.0 & Albert (2002) \\
\hline & & & & Landsat TM (25 Jul 1985) & & 55.7 & Salzmann et al. (2013) \\
\hline 1988 & Landsat TM (3 Sep 1988) & 57.7 & 52.8 & SPOT (29 Aug 1988) & & 54.0 & Albert (2007) \\
\hline 1998 & Landsat TM (29 Jul 1998) & 51.2 & 47.7 & SPOT (8 Aug 1998) & & 47.3 & Albert (2007) \\
\hline 2006 & Landsat TM (19 Jul 2006) & 47.8 & 44.4 & ASTER (Unknown) & & 44.2 & Salzmann et al. (2013) \\
\hline 2008 & Landsat TM (25 Aug 2008) & 46.7 & 43.7 & ASTER (Unknown) & & 42.8 & Salzmann et al. (2013) \\
\hline 2009 & Landsat TM (15 Oct 2009$)$ & 45.1 & 42.8 & ASTER (Unknown) & & 42.8 & Salzmann et al. (2013) \\
\hline
\end{tabular}

included in measurements where we discuss the entire CV. For their definition of the CV extent, between 1985 and 2006, Salzmann et al. (2013) report a $33 \%$ loss in glacierized area. Over a similar time frame, from 1988 to 2010 , our study reports a $30 \%$ loss in area. Our definition of the extent of the $\mathrm{CV}$ region may incorporate slightly differing glacierized regions; however, the trends are comparable.

For their definition of the CV, Salzmann et al. (2013) report areas that produce high decline rates $\left(9.1 \mathrm{~km}^{2} \mathrm{yr}^{-1}\right)$ from 1985 to 1996 followed by slower decline rates $(4.7$ $\mathrm{km}^{2} \mathrm{yr}^{-1}$ ) from 1996 to 2006, based on two images (and area measurements) per time period (Fig. 10). Our decline rates are based on more than two area measurements per time period (for 1988-1999, $n=3$, and for 2000-2010, $n=5$ ), thereby reducing the error associated with potentially using two endmember measurements that may not be the minimum area measurement for that year. We have calculated decline rates for four different time periods (Table 3). Our study indicates that the different glacierized regions are declining at different rates, and finds that area-normalized decline rates for the majority of glacierized regions investigated ( 8 of 10) are highest during the period 2000-2010. This increase in areal decline rates is an important finding, as areas reported by Salzmann et al. (2013) suggest that decline rates have decreased between 1996 to 2006 compared with 1985 to 1996. Although glacial areas (and decline rates) appear to be higher (lower) in the early to mid-2000s, the decline rates during the decade from 2000 to 2010 are higher than for previous intervals. Our study suggests that decline rates have increased for most glacierized areas in the $\mathrm{CV}$ region compared to the 1980s and 1990s.

We investigated the areal glacial retreat behavior with respect to elevation by analyzing the median elevation of a glacier through time. We observed that all median glacial elevations rose through time, but their rates differed with respect to elevation (Fig. 14). Glacierized areas with lower median elevations are retreating faster than glacierized areas at higher elevations (Fig. 14). For the four largest glacierized areas $\left(>20 \mathrm{~km}^{2}\right)$ in the CV and just beyond, the median elevation gain ranged from $2.02 \pm 0.21 \mathrm{~m} \mathrm{yr}^{-1}$ to $2.98 \pm 0.34 \mathrm{~m} \mathrm{yr}^{-1}$. Median glacial elevations around $5200 \mathrm{~m}$ a.s.l. have been retreating to higher elevations at a rate of almost $1 \mathrm{~m} \mathrm{yr}^{-1}$ faster than glaciers located only $200 \mathrm{~m}$ higher at $5400 \mathrm{~m}$ a.s.l. These results reflect those found in Rabatel et al. (2013), specifically, that glaciers lower than $5400 \mathrm{~m}$ a.s.l. have been losing mass at a greater rate $\left(1.2 \mathrm{~m}\right.$ w.e. $\mathrm{yr}^{-1}$ (meters of water equivalent $\left.\mathrm{yr}^{-1}\right)$ ) than those glaciers located higher than $5400 \mathrm{~m}$ a.s.l. $\left(0.6 \mathrm{~m}\right.$ w.e. $\left.\mathrm{yr}^{-1}\right)$. The majority of glaciers in this region terminate around 4700-5000 m a.s.l. (Salzmann et al., 2013) and will thus retreat more rapidly to higher elevations before retreat rates are likely to decrease.

We have investigated decline rates, glacial-area, and median area changes to larger glacierized units, but recognize that some of the areas are large and comprise glaciers with different altitudes, aspects, and slopes. In order to analyze smaller glacial units, we have delineated individual glacial watersheds using the SRTM DEM and have calculated the decline rates for each glacial basin (Fig. 15). In total, we analyzed 212 glacial basins with glacial areas ranging from less than $1 \mathrm{~km}^{2}$ to a few dozen $\mathrm{km}^{2}$, with a mean area of $3 \mathrm{~km}^{2}$. Despite some scatter in the data, we observe that glaciers with lower median elevations have higher decline rates than glaciers at higher elevations (Fig. 15). This finding corroborates our earlier findings (Fig. 14) and shows the strong altitudinal dependence on glacial retreat. We further investigated this pattern by analyzing retreat behavior with respect to their watershed aspect and hypsometric integral, but do not find significant correlation (Figs. S13 and S14, respectively). 


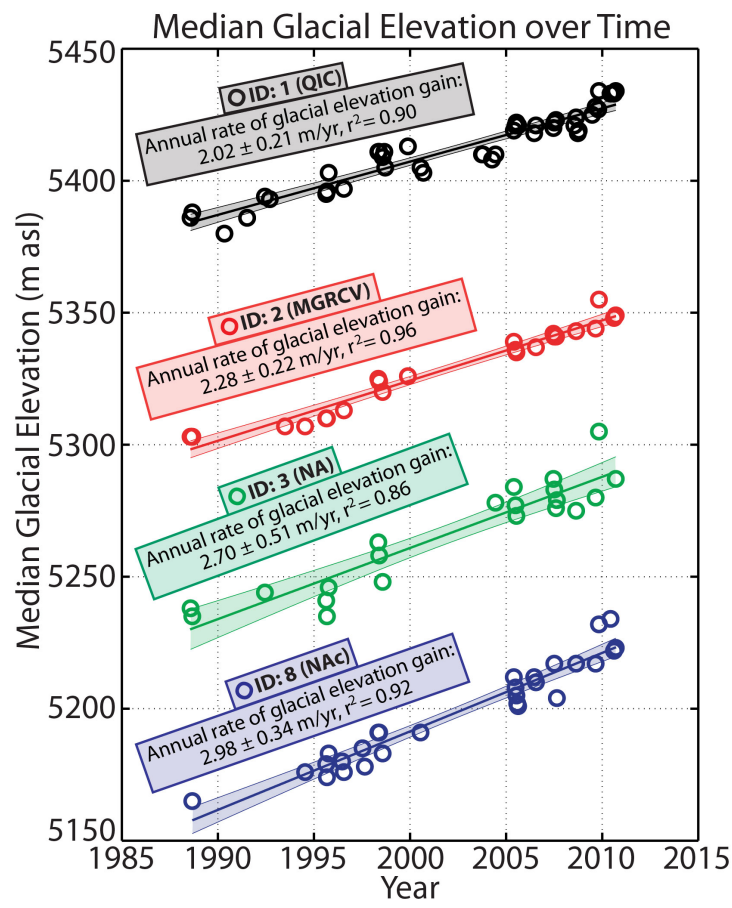

Fig. 14. Median glacial elevation $( \pm 95 \% \mathrm{CI})$ against the time series of this study for the four largest glacierized IDs in this region (IDs 1: Quelccaya Ice Cap (QIC), 2: main glacierized region of the CV (MGRCV), 3: Nevado Ausangate region (NA), and 8: Nevado Allincapac region (NAc), a glacierized area just beyond the eastern boundary of the $\mathrm{CV}$ ).

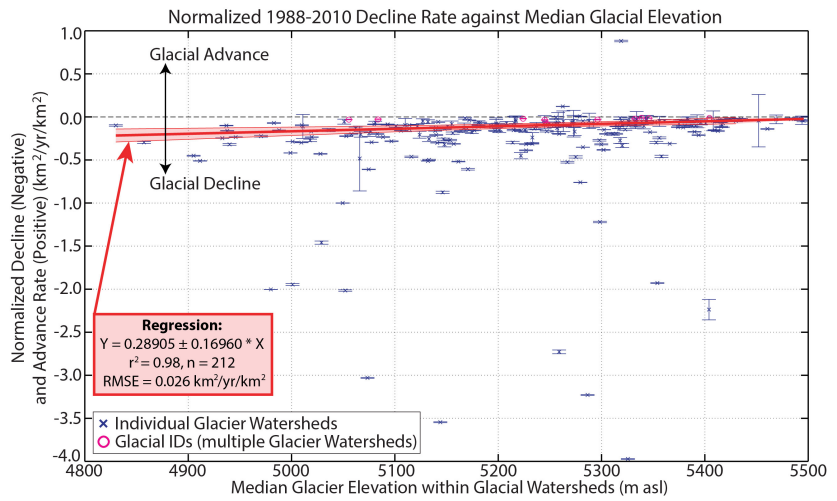

Fig. 15. Normalized (against median area) decline rates against median glacial elevation within individual glacial watersheds. Watersheds were delineated using the SRTM DEM and standard GIS procedures. A total of 212 glacial watersheds were used to calculate decline rates for each watershed basin based on the satellite-image time series. Watershed areas range from $<1 \mathrm{~km}^{2}$ to a few dozen $\mathrm{km}^{2}$ with a mean area of $3 \mathrm{~km}^{2}$. Error bars of the regression indicate $95 \%$ CI.

\subsection{Lake area changes}

Growth of Lake ID 33 (located in front of Qori Kalis glacier in the QIC) (Fig. 12a) has been previously documented (Brecher and Thompson, 1993; Thompson et al., 2006) and reflects the retreat of Qori Kalis glacier (Fig. 13). Both the 1991-2005 retreat rate of $\sim 60 \mathrm{~m} \mathrm{yr}^{-1}$ from Thompson et al. (2006) and this study's retreat rate of $\sim 67 \mathrm{~m} \mathrm{yr}^{-1}$ correspond with the time period during which this lake experienced the majority of its growth. The period 2000-2005 showed even greater lake growth than during the previous 9 years since 1991. This reflects our findings in this study of the higher glacial decline rates during the 2000s than during the 1990s, and the related growth of this proglacial lake in correspondence to this.

Although variability exists, it is evident in both Fig. 11 and Fig. 12 that these lakes have significantly increased in area coeval with the decrease in upstream glacial area. All lakes have formed since 1985, but the late 1990s and early 2000s exhibited the strongest lake growth. Individual timing of lake growth, however, is likely also influenced by other factors local to each lake, such as topography on ice or ice margin, or proximity to glacial edge, etc. Note how Lake IDs 33 and 25 appear to have stabilized since 2005, and Lake IDs 8,26 , and 35 appear to have begun to decrease in area, which at least visually appears to correspond with the glacial margin retreating further from the lake edge itself.

No studies currently exist examining proglacial and glacier-fed lake area changes in the northern central Andes. This is the first regional study summarizing lake area changes derived from satellite imagery. The majority of lakes in this region that we tracked have been small: 42 out of 50 (or $84 \%$ ) are less than $2 \mathrm{~km}^{2}$, and only 3 out of 50 (or $6 \%$ ) are larger than $5 \mathrm{~km}^{2}$, resulting in a mean area of $2.7 \mathrm{~km}^{2}$ and a median area of $0.3 \mathrm{~km}^{2}$ (based on most recent Landsat TM lake area). The majority of the lakes we have investigated (both small and large) have measurements that fluctuate around a relatively stable area, and do not show significant lake-area changes (growth or decline) beyond their uncertainties (examples of these can be found in the Supplement, cf. Fig. S15). These fluctuations are likely a result of some lake area changes, as well as classification methodology, specifically that many images required different thresholds to outline the same lake area visually. However, some of the lakes (particularly the proglacial lakes) show significant lake area changes that extend beyond their uncertainties. We have shown the results for five proglacial lakes in this study (Fig. 11 and Fig. 12) that have rapidly developed since 1985. The development of these lakes reflects glacial retreat in this region, with the period 2000-2010 showing greater lake growth than during the previous 8 years since 1992, or 15 years since 1985 . This agrees with our findings of higher glacial decline rates during the 2000s than during the 1990s.

Areas of these proglacial lakes began to increase rapidly during the mid- to late 1990s. A possible explanation for this 


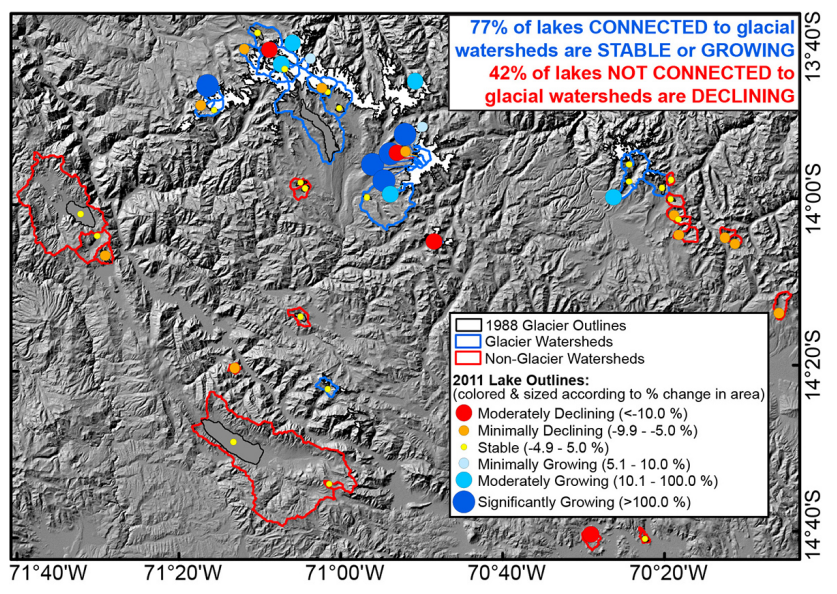

Fig. 16. Regional trends in lakes throughout the study area, indicating relative change (\%) in lake area between earliest and most recent Landsat TM measurement: stable lakes are those with change only between $-4.9 \%$ and $+5.0 \%$; declining lakes have negative change; and growing lakes have positive change. Lake watersheds that contain glacial regions are delineated in blue, and those that do not contain glacial regions are delineated in red. Glacial regions are in white and outlined in black, and the SRTM DEM hillshade is shown in the background. We have not included Laguna Sibinacocha (Lake ID 2, Fig. 8a) in these analyses as it has been a managed lake since the completion of the dam in 1996.

lake growth is the influence of the El Niño-Southern Oscillation (ENSO), which has been suggested to impact glacial behavior in this region (Rabatel et al., 2013; Vuille et al., 2008a; Albert, 2007; Perry et al., 2013; Thompson et al., 2013; Morales et al., 2012). This also corresponds well with the significant decrease in glacial area during the strong positive ENSO event of 1998. At least, the coincidence in timing to other lake-area observations and the increase in glacialmelt rates likely point to a regional climatic signal.

In order to put our analysis into a spatial context, we show the lake-area trends for all 50 identified lakes (Fig. 16). Using the SRTM-DEM delineated watersheds for each of the lakes, we identified whether they were fluvially connected to glaciers upstream or not based on whether any of the resulting watersheds overlapped with any glacial areas (i.e., we presume connectivity to glaciers if any glacial area is within the extent of each of the 50 lake catchments). In Fig. 16 we have calculated the relative change of each lake between the most recent lake area and the earliest lake area (using Landsat TM images only, 1985 to 2011) in percent: positive values indicate growing regions, and negative values indicate declining regions. All first and last lake-area measurements are reported in the Supplement (Table S3).

The majority of lakes both with and without connectivity to glaciers are relatively stable. While some lakes connected to glaciers have declined, no lakes not connected to glaciers have grown. Specifically, $44 \%$ of all lakes (both connected and not connected to glacial watersheds) are stable. However,
$23 \%$ of lakes connected to glacial watersheds have declined, while $40 \%$ have grown. In contrast, $42 \%$ of lakes not connected to glacial watersheds have declined, while $0 \%$ have grown. This suggests again that lakes with glaciers within their catchments are benefiting from the increased glacial melting that has occurred over the time period of this study. Some glacial drainage basins are characterized by cascading lakes, and we observe that some lakes within these watersheds are growing, while the remainder may show an areally stable, or even declining, signal - for example, the northwesterly downstream section of Glacial ID 2 (Fig. 8a).

In order to assess the temporal behavior of lake-area changes, we have divided the time series into 5 year increments and have calculated the rate of lake change by fitting a robust regression through all lake-area measurements within that time period (Fig. 17). Despite some scatter in the data, a clear signal emerges: lakes connected to glaciers have been growing from 1985 through 2005 with the highest growth rate in the 1995-2000 time interval. Between 2005 and 2010, the majority of these lakes have been declining. In contrast, lakes not connected to glaciers have declined in 1985 through 1995, but increased during 1995-2000, likely because of a climatic forcing. From 2005 to 2010, lake areas have been declining for lakes not connected to glaciers. These findings are supported by only analyzing lake areas at the beginning and end of each 5 year interval (Fig. S17).

To summarize, proglacial lakes (e.g., those shown in Figs. 11 and 12) are in good spatial and temporal agreement with glacial melting. Case studies on natural hazards including GLOFs have been documented in the Cordillera Blanca of Peru (Carey, 2005; Hubbard et al., 2005; Vilímek et al., 2005; Hegglin and Huggel, 2008), north of this study area, but as of yet no studies exist investigating these hazards in this region, and so it is unknown whether the growth of these proglacial lakes poses an immediate hazard or not. The proglacial lakes we have investigated show a variety of responses but an overall positive trend. The net response of lakes not connected to glacial watersheds is more clear: these are either remaining stable or declining, but have shown no net growth over the 1985-2012 time period of this study.

\subsection{Snow lines}

Remote sensing studies in recent years have used the transient snow line at the end of the dry/cold period as a proxy for the equilibrium line altitude (ELA) of a given year (Klein and Isacks, 1999; Østrem, 1975; Mathieu et al., 2009; Clare et al., 2002). While previously the use of the snow line to estimate the ELA in the outer tropics was based on assumption of correlation, a recent study (Rabatel et al., 2012) confirms, with some caveats (specifically, the necessity of validation), that the highest altitude reached by the snow line over the course of the entire dry/cold season may provide an estimate of the ELA for that year (although it is likely an underestimation). 

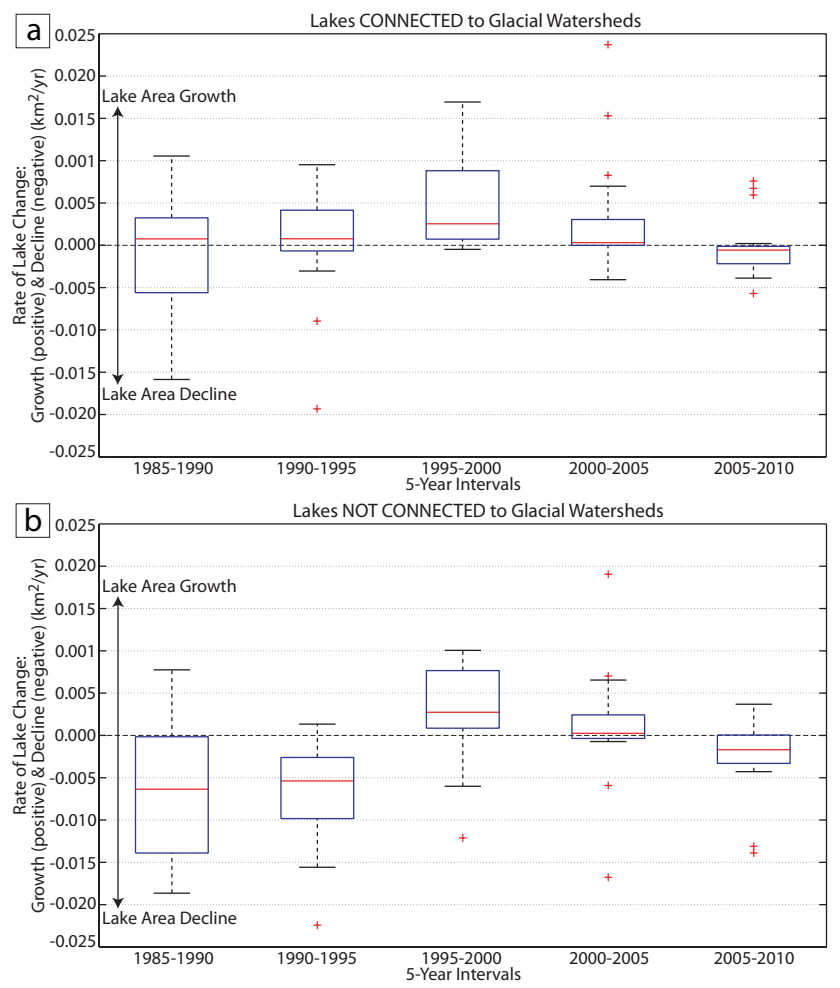

Fig. 17. Rate of lake-area changes within 5 year time intervals for (a) lakes connected to glacial watersheds, and (b) lakes not connected to glacial watersheds.

Very few measurements of snow lines currently exist in this region, and those that do date back to the 1960s and 1970s, with no more recent measurements. Additionally, it is unknown how the previous studies have measured the snow line (i.e., on what date, on what point of the glacier, whether it is a mean measurement, as the snow line is rarely consistent around the glacier, or a maximum measurement, etc.). As a result, we are unable to validate our snow-line measurements to determine whether they approximate the ELA for each year or not. The measurements presented in this study have been created by a consistent method, and the relative patterns should be accurate due to this consistency.

During the 1990s and 2000s, glacial retreat has been significant and is reflected by our snow-line changes between 1988 and 2009 (Fig. S18). The year 1998 exhibited a particularly high snow-line altitude (5526 m a.s.l.), corresponding to an AAR of $13 \%$. We note again that 1998 corresponds to a strong positive ENSO event, and we also observed lower-than-average glacial-area measurements during this year (Figs. 9, 10 and S3 to S11 in the Supplement). An AAR of $13 \%$ calculated from this snow line is unsustainable. Even a rise in snow-line altitude (SLA) of $182 \mathrm{~m}$ between 1988 and 1998 seems unrealistic. However, this has also been reported for the Zongo Glacier in Bolivia to the south, which experienced an increase in ELA of $\sim 225 \mathrm{~m}$ between even 1996/1997 (ELA $5075 \mathrm{~m}$ a.s.1.) and 1997/1998 (ELA $\sim 5300 \mathrm{~m}$ a.s.l.) (Rabatel et al., 2012). During the following $1998 / 1999$ water year, they reported the ELA for Zongo to be $\sim 200 \mathrm{~m}$ lower again, $\sim 5100 \mathrm{~m}$ a.s.l. In the light of these results, our findings of the SLA increase for the QIC are not unreasonable and correspond well with the change in snow line and equilibrium line altitudes of the Zongo Glacier. This 1998 snow-line and AAR measurement appears to be an endmember, while the 1988 and 2009 snow-line and AAR measurements appear more reasonable.

Based on the relationship between SLA and ELA as reported in Rabatel et al. (2012), our measurements are likely to represent underestimates of the ELA for the given years (as the SLA on satellite images tends to be an underestimate of the true ELA; Rabatel et al., 2012). AARs derived from the 1988 and 2009 snow lines (63\% and $53 \%$, respectively) also indicate positive glacier mass balances (AAR $>50 \%$ ), yet given the glacial decline shown in this and other studies, this is clearly not the case. This also lends support to suggest that our snow lines are lower (underestimates) than the true equilibrium line altitudes for 1988 and 2009 at least.

\section{Conclusions}

This study makes use of a multitude of multi-spectral satellite images to obtain time series of glacial and lake areas throughout the Cordillera Vilcanota (CV) in the northern central Andes from 1975 to 2012. In addition, we report three snow lines spanning 21 years for the Quelccaya Ice Cap (QIC).

Our results indicate that glacierized areas have been strongly declining throughout the CV. Smaller glacierized areas have, in general, higher decline rates than those of larger glacierized areas; however, the trends in decline rates are similar for glacierized areas of all sizes: decline rates have been higher during the most recent decade (2000-2010) than during the previous decade (1988-1999). Glacierized regions at lower elevations also have higher decline rates than those at higher elevations. Between 1988 and 2009, the AAR of the QIC has decreased, as the snow line has retreated to a higher elevation. The strong positive ENSO event during 1998 is a possible driver for the large decline in glacial area during that time period and an explanation for the extremely high snow line observed for the QIC during this year.

The retreat of glacierized regions throughout the $\mathrm{CV}$ and beyond has provided increased meltwaters to the downstream lakes of the region. Proglacial lakes have formed since the beginning of our study's time series. The majority of proglacial lake growth has occurred since the mid- to late 1990s, which corresponds well with the increase in glacial decline rates. Spatially, it is evident that lakes downstream of glacial watersheds are either stable $(37 \%)$ or growing $(40 \%)$, while those lakes not downstream of glacial watersheds are mostly remaining stable $(58 \%)$ or declining $(42 \%)$. 
Data from this study provide the most consistent longterm time series of glacier and lake area measurements for the Quelccaya Ice Cap and the Cordillera Vilcanota region of Peru. Consistency of methodologies and data sources was maintained over the period of study and contributes to robust map products. These data can be both incorporated into the GLIMS database, and also be used to gain a more indepth understanding of recent glacial and lake area changes throughout the Cordillera Vilcanota, given that documenting and understanding past changes is a first step in preparing for future changes and consequences.

\section{Supplementary material related to this article is available online at http://www.the-cryosphere.net/8/359/ 2014/tc-8-359-2014-supplement.pdf.}

Acknowledgements. This work (specifically, M. N. Hanshaw) was supported by NASA Headquarters under the NASA Earth and Space Science Fellowship Program. All Landsat images are courtesy of the US Geological Survey, who also processed and compiled the Corona imagery. ASTER imagery was provided by NASA Reverb. We would also like to thank D. A. Roberts and M. Alonzo for their advice on spectral unmixing, L. Carvalho for comments, B. Mark and P. Burns for their assistance in finding area measurements for the Quelccaya Ice Cap, and N. Salzmann for providing us with an advance copy of their final manuscript. Additionally, we thank the editor A. Klein, C. Huggel, M. Pelto, and an anonymous reviewer for their valuable comments, which improved the manuscript.

Edited by: A. Klein

\section{References}

Albert, T. H.: Evaluation of Remote Sensing Techniques for IceArea Classification Applied to the Tropical Quelccaya Ice Cap, Peru, Polar Geogr., 26, 210-226, doi:10.1080/789610193, 2002.

Albert, T. H.: Assessing Glacier Mass Balances from Small Tropical Glaciers to the Large Ice Sheet of Greenland, Florida State University, 2007.

Barnett, T. P., Adam, J. C., and Lettenmaier, D. P.: Potential impacts of a warming climate on water availability in snow-dominated regions, Nature, 438, 303-309, doi:10.1038/nature04141, 2005.

Bolch, T., Buchroithner, M. F., Peters, J., Baessler, M., and Bajracharya, S.: Identification of glacier motion and potentially dangerous glacial lakes in the Mt. Everest region/Nepal using spaceborne imagery, Nat. Hazards Earth Syst. Sci., 8, 13291340, doi:10.5194/nhess-8-1329-2008, 2008.

Bookhagen, B. and Burbank, D. W.: Toward a complete Himalayan hydrological budget: Spatiotemporal distribution of snowmelt and rainfall and their impact on river discharge, J. Geophys. Res., 115, F03019, doi:10.1029/2009JF001426, 2010.

Bookhagen, B. and Strecker, M. R.: Orographic barriers, high-resolution TRMM rainfall, and relief variations along the eastern Andes, Geophys. Res. Lett., 35, L06403, doi:10.1029/2007GL032011, 2008.
Bookhagen, B. and Strecker, M. R.: Spatiotemporal trends in erosion rates across a pronounced rainfall gradient: Examples from the southern Central Andes, Earth Planetary Sc. Lett., 327-328, 97-110, doi:10.1016/j.epsl.2012.02.005, 2012.

Bradley, R. S., Vuille, M., Diaz, H. F., and Vergara, W.: Threats to Water Supplies in the Tropical Andes, Science, 312, 1755-1756, 2006.

Brecher, H. H. and Thompson, L. G.: Measurement of the Retreat of Qori Kalis Glacier in the Tropical Andes of Peru by Terrestrial Photogrammetry, Photogramm. Eng. Rem. S., 59, 1017-1022, 1993.

Bronge, L. B. and Bronge, C.: Ice and snow-type classification in the Vestfold Hills, East Antarctica, using Landsat-TM data and ground radiometer measurements, Int. J. Remote Sens., 20, 225240, 1999.

Carey, M.: Living and dying with glaciers: people's historical vulnerability to avalanches and outburst floods in Peru, Global and Planet. Change, 47, 122-134, doi:10.1016/j.gloplacha.2004.10.007, 2005.

Chan, J. C.-W., Van Ophem, J., and Huybrechts, P.: Estimation of accumulation area ratio of a glacier from multi-temporal satellite images using spectral unmixing, IEEE Geosci. Remote S. Symposium, 2, 606-609, 2009.

Clare, G. R., Fitzharris, B. B., Chinn, T. J. H., and Salinger, M. J.: Interannual variation in end-of-summer snowlines of the Southern Alps of New Zealand, and relationships with Southern Hemisphere atmospheric circulation and sea surface temperature patterns, Int. J. Climatol., 22, 107-120, doi:10.1002/joc.722, 2002.

Farr, T. G., Rosen, P. A., Caro, E., Crippen, R., Duren, R., Hensley, S., Kobrick, M., Paller, M., Rodriguez, E., Roth, L., Seal, D., Shaffer, S., Shimada, J., Umland, J., Werner, M., Oskin, M., Burbank, D. W., and Alsdorf, D.: The Shuttle Radar Topography Mission, Rev. Geophys., 45, RG2004, doi:10.1029/2005RG000183, 2007.

Gardelle, J., Arnaud, Y., and Berthier, E.: Contrasted evolution of glacial lakes along the Hindu Kush Himalaya mountain range between 1990 and 2009, Global Planet. Change, 75, 47-55, doi:10.1016/j.gloplacha.2010.10.003, 2011.

Georges, C.: 20th-Century Glacier Fluctuations in the Tropical Cordillera Blanca, Peru, Arct. Antarc. Alp. Res., 36, 100-107, 2004.

Hall, D. K., Ormsby, J. P., Bindschadler, R. A., and Siddalingaiah, H.: Characterization of snow and ice reflectance zones on glaciers using Landsat Thematic Mapper data, Ann. Glaciol., 9, 104-108, 1987.

Hastenrath, S.: Heat-budget measurements on the Quelccaya Ice Cap, Peruvian Andes, J. Glaciol., 20, 85-97, 1978.

Hastenrath, S.: Cordillera Blanca on Landsat imagery and Quelccaya Ice Cap, in Satellite Image Atlas of the World - South America, edited by: Williams, R. and Ferrigno, J., USGS Professional Paper 1386-I, 1998.

Hegglin, E. and Huggel, C.: An Integrated Assessment of Vulnerability to Glacial Hazards, Mt. Res. Dev., 28, 299-309, doi:10.1659/mrd.0976, 2008.

Hidrandina, S. A.: Glacier Inventory of Perú, Consejo Nacional de Ciencia y Technología, Perú, 1988.

Hubbard, B., Heald, A., Reynolds, J. M., Quincey, D., Richardson, S. D., Luyo, M. Z., Portilla, N. S., and Hambrey, M. J.: Impact of a rock avalanche on a moraine-dammed proglacial lake: Laguna 
Safuna Alta, Cordillera Blanca, Peru, Earth Surf. Proc. Land., 30, 1251-1264, doi:10.1002/esp.1198, 2005.

Huggel, C., Kääb, A., Haeberli, W., Teysseire, P., and Paul, F.: Remote sensing based assessment of hazards from glacier lake outbursts: a case study in the Swiss Alps, Can. Geotech. J., 39, 316330, doi:10.1139/T01-099, 2002.

Huggel, C., Salzmann, N., Allen, S., Caplan-Auerbach, J., Fischer, L., Haeberli, W., Larsen, C., Schneider, D., and Wessels, R. L.: Recent and future warm extreme events and highmountain slope stability, Philos. T. Roy. Soc. A, 368, 2435-2459, doi:10.1098/rsta.2010.0078, 2010.

IPCC: Climate Change 2007: The Physical Science Basis, in: Contribution of Working Group I to the Fourth Assessment Report of the Intergovernmental Panel on Climate Change, edited by: Solomon, S., Qin, D., Manning, M., Chen, Z., Marquis, M., Averyt, K. B., Tignor, M., and Miller, H. L., Cambridge University Press, Cambridge, United Kingdom and New York, NY, USA, 2007.

Kaser, G. and Georges, C.: On the mass balance of low latitude glaciers with particular consideration of the Peruvian Cordillera Blanca, Geogr. Ann., 81A, 643-651, 1999.

Kaser, G., Großhauser, M., and Marzeion, B.: Contribution potential of glaciers to water availability in different climate regimes, P. Natl. Acad. Sci. USA, 107, 20223-20227, doi:10.1073/pnas.1008162107, 2010.

Klein, A. G. and Isacks, B. L.: Spectral mixture analysis of Landsat thematic mapper images applied to the detection of the transient snowline on tropical Andean glaciers, Global Planet. Change, 22, 139-154, doi:10.1016/S0921-8181(99)00032-6, 1999.

Mark, B. G., Seltzer, G. O., Rodbell, D. T., and Goodman, A. Y.: Rates of Deglaciation during the Last Glaciation and Holocene in the Cordillera Vilcanota-Quelccaya Ice Cap Region, Southeastern Perú, Quaternary Res., 57, 287-298, doi:10.1006/qres.2002.2320, 2002.

Masek, J. G., Honzak, M., Goward, S. N., Liu, P., and Pak, E.: Landsat-7 ETM+ as an observatory for land cover: Initial radiometric and geometric comparisons with Landsat-5 Thematic Mapper, Remote Sens. Environ., 78, 118-130, 2001.

Mathieu, R., Chinn, T., and Fitzharris, B.: Detecting the equilibrium-line altitudes of New Zealand glaciers using ASTER satellite images, New Zeal. J. Geolo. Geop., 52, 209-222, 2009.

Mercer, J. H. and Palacios, O. M.: Radiocarbon dating of the last glaciation in Perú, Geology, 5, 600-604, 1977.

Morales, M. S., Christie, D. A., Villalba, R., Argollo, J., Pacajes, J., Silva, J. S., Alvarez, C. A., Llancabure, J. C., and Soliz Gamboa, C. C.: Precipitation changes in the South American Altiplano since $1300 \mathrm{AD}$ reconstructed by tree-rings, Clim. Past, 8, 653-666, doi:10.5194/cp-8-653-2012, 2012.

Morales Arnao, B.: Glaciers of Peru, in: Satellite Image Atlas of the World - South America, edited by: Williams, R. and Ferrigno, J., USGS Professional Paper 1386-I, 1998.

Østrem, G.: ERTS data in glaciology - an effort to monitor glacier mass balance from satellite imagery, J. Glaciol., 15, 403-415, 1975.

Painter, T. H., Roberts, D. A., Green, R. O., and Dozier, J.: The effect of grain size on spectral mixture analysis of snow-covered area from AVIRIS data, Remote Sens. Environ., 65, 320-332, 1998.
Paul, F. and Kääb, A.: Perspectives on the production of a glacier inventory from multispectral satellite data in Arctic Canada: Cumberland Peninsula, Baffin Island, Ann. Glaciol., 42, 59-66, 2005.

Paul, F., Barry, R. G., Cogley, J. G., Frey, H., Haeberli, W., Ohmura, A., Ommanney, C. S. L., Raup, B., Rivera, A., and Zemp, M.: Recommendations for the compilation of glacier inventory data from digital sources, Ann. Glaciol., 50, 119-126, 2009.

Paul, F., Barrand, N. E., Baumann, S., Berthier, E., Bolch, T., Casey, K., Frey, H., Joshi, S. P., Konovalov, V., Le Bris, R., Mölg, N., Nosenko, G., Nuth, C., Pope, A., Racoviteanu, A., Rastner, P., Raup, B., Scharrer, K., Steffen, S., and Winsvold, S.: On the accuracy of glacier outlines derived from remote-sensing data, A. Glaciol., 54, 171-182, doi:10.3189/2013AoG63A296, 2013.

Perry, L. B., Seimon, A., and Kelly, G. M.: Precipitation delivery in the tropical high Andes of southern Peru: new findings and paleoclimatic implications, Int. J. Climatol., doi:10.1002/joc.3679, 2013.

Rabatel, A., Dedieu, J.-P., and Vincent, C.: Using remote-sensing data to determine equilibrium-line altitude and mass-balance time series: validation on three French glaciers, 1994-2002, J. Glaciol., 51, 539-546, 2005.

Rabatel, A., Bermejo, A., Loarte, E., Soruco, A., Gomez, J., Leonardini, G., Vincent, C., and Sicart, J. E.: Can the snowline be used as an indicator of the equilibrium line and mass balance for glaciers in the outer tropics?, J. Glaciol., 58, 1027-1036, doi:10.3189/2012JoG12J027, 2012.

Rabatel, A., Francou, B., Soruco, A., Gomez, J., Cáceres, B., Ceballos, J. L., Basantes, R., Vuille, M., Sicart, J.-E., Huggel, C., Scheel, M., Lejeune, Y., Arnaud, Y., Collet, M., Condom, T., Consoli, G., Favier, V., Jomelli, V., Galarraga, R., Ginot, P., Maisincho, L., Mendoza, J., Ménégoz, M., Ramirez, E., Ribstein, P., Suarez, W., Villacis, M., and Wagnon, P.: Current state of glaciers in the tropical Andes: a multi-century perspective on glacier evolution and climate change, The Cryosphere, 7, 81102, doi:10.5194/tc-7-81-2013, 2013.

Racoviteanu, A. E., Arnaud, Y., Williams, M. W., and Ordoñez, J.: Decadal changes in glacier parameters in the Cordillera Blanca, Peru, derived from remote sensing, J. Glaciol., 54, 499-510, 2008a.

Racoviteanu, A. E., Williams, M. W., and Barry, R. G.: Optical Remote Sensing of Glacier Characteristics: A Review with Focus on the Himalaya, Sensors, 8, 3355-3383, doi:10.3390/s8053355, 2008 b.

Racoviteanu, A. E., Paul, F., Raup, B., Khalsa, S. J. S., and Armstrong, R.: Challenges and recommendations in mapping of glacier parameters from space: results of the 2008 Global Land Ice Measurements from Space (GLIMS) workshop, Boulder, Colorado, USA, Ann. Glaciol., 50, 53-69, 2009.

Roberts, D. A., Gardner, M., Church, R., Ustin, S., Scheer, G., and Green, R. O.: Mapping Chaparral in the Santa Monica Mountains using Multiple Endmember Spectral Mixture Models, Remote Sens. Environ., 65, 267-279, 1998.

Roberts, D. A., Halligan, K., and Dennison, P.: VIPER Tools User Manual, UC Santa Barbara, Department of Geography, Version 1.7, 1-91, 2007.

Salzmann, N., Huggel, C., Rohrer, M., Silverio, W., Mark, B. G., Burns, P., and Portocarrero, C.: Glacier changes and climate trends derived from multiple sources in the data scarce Cordillera 
Vilcanota region, southern Peruvian Andes, The Cryosphere, 7, 103-118, doi:10.5194/tc-7-103-2013, 2013.

Silverio, W. and Jaquet, J.: Glacial cover mapping (1987-1996) of the Cordillera Blanca (Peru) using satellite imagery, Remote Sens. Environ., 95, 342-350, doi:10.1016/j.rse.2004.12.012, 2005.

Soruco, A., Vincent, C., Francou, B., and Gonzalez, J. F.: Glacier decline between 1963 and 2006 in the Cordillera Real, Bolivia, Geophys. Res. Lett., 36, L03502, doi:10.1029/2008GL036238, 2009.

Surazakov, A. and Aizen, V.: Positional accuracy evaluation of declassified Hexagon KH-9 mapping camera imagery, Camera, 76, 603-608, 2010.

Svoboda, F. and Paul, F.: A new glacier inventory on southern Baffin Island, Canada, from ASTER data: I. Applied methods, challenges and solutions, Ann. Glaciol., 50, 11-21, 2009.

Thompson, L. G.: Glaciological investigations of the tropical Quelccaya ice cap, Peru, J. Glaciol., 25, 69-84, 1980.

Thompson, L. G., Hastenrath, S., and Arnao, B. M.: Climatic Ice Core Records from the Tropical Quelccaya Ice Cap, Science, 203, 1240-1243, doi:10.1126/science.203.4386.1240, 1979.

Thompson, L. G., Mosley-Thompson, E., Bolzan, J. F., and Koci, B. R.: A 1500-Year Record of Tropical Precipitation in Ice Cores from the Quelccaya Ice Cap, Peru, Science, 229, 971-973, 1985.

Thompson, L. G., Mosley-Thompson, E., Brecher, H., Davis, M., León, B., Les, D., Lin, P.-N., Mashiotta, T., and Mountain, K.: Abrupt tropical climate change: past and present., P. Natl. Acad. Sci. USA, 103, 10536-10543, doi:10.1073/pnas.0603900103, 2006.

Thompson, L. G., Mosley-Thompson, E., Davis, M. E., Zagorodnov, V. S., Howat, I. M., Mikhalenko, V. N., and Lin, P.-N.: Annually Resolved Ice Core Records of Tropical Climate Variability Over the Past $\sim 1800$ Years, Science, 340, 945-950, doi:10.1126/science.1234210, 2013.
Vergara, W., Deeb, A. M., Valencia, A. M., Bradley, R. S., Francou, B., Zarzar, A., Grünwaldt, A., and Haeussling, S. M.: Economic Impacts of Rapid Glacier Retreat in the Andes, EOS Transactions, American Geophysical Union, 88, 261-268, doi:10.1029/2007EO250001, 2007.

Vilímek, V., Zapata, M. L., Klimeš, J., Patzelt, Z., and Santillán, N.: Influence of glacial retreat on natural hazards of the Palcacocha Lake area, Peru, Landslides, 2, 107-115, doi:10.1007/s10346005-0052-6, 2005.

Vuille, M., Francou, B., Wagnon, P., Juen, I., Kaser, G., Mark, B. G., and Bradley, R. S.: Climate change and tropical Andean glaciers: Past, present and future, Earth Sci. Rev., 89, 79-96, doi:10.1016/j.earscirev.2008.04.002, 2008a.

Vuille, M., Kaser, G., and Juen, I.: Glacier mass balance variability in the Cordillera Blanca, Peru and its relationship with climate and the large-scale circulation, Global Planet. Change, 62, 1428, doi:10.1016/j.gloplacha.2007.11.003, 2008b.

Wessels, R. L., Kargel, J. S., and Kieffer, H. H.: ASTER measurement of supraglacial lakes in the Mount Everest region of the Himalaya, Ann. Glaciol., 34, 399-408, doi:10.3189/172756402781817545, 2002.

WGMS and NSIDC: World Glacier Inventory, Compiled and made available by the World Glacier Monitoring Service, Zurich, Switzerland, and the National Snow and Ice Data Center, Boulder CO, USA Digital Media (updated 2009), 1989.

Yu, J., Liu, H., Wang, L., Jezek, K. C., and Heo, J.: Blue ice areas and their topographical properties in the Lambert glacier, Amery Iceshelf system using Landsat ETM+, ICESat laser altimetry and ASTER GDEM data, Antarctic Sci., 24, 95-110, doi:10.1017/S0954102011000630, 2012. 